\title{
KONSEP TAUBAT MENURUT ISLAM DAN KRISTIAN DARI PERSPEKTIF PERBANDINGAN*
}

THE CONCEPT OF REPENTANCE IN ISLAM AND CHRISTIANITY FROM COMPARATIVE PERSPECTIVES

\section{Sri Rahayu Haji Dollah*, Khadijah Mohd Hambali @ Khambali $^{* *}$}

${ }^{* *}$ Academy of Islamic Studies. University of Malaya. 50603. Kuala Lumpur. Malaysia.

Email: *ratna7676@yahoo.com

\begin{abstract}
Khulasah
Taubat dalam agama Islam dan Kristian merupakan salah satu kaedah penyucian jiwa yang ditetapkan untuk para penganut mereka. Kedua-dua agama ini menetapkan taubat sebagai jalan penghubung antara Tuhan dengan manusia, di samping langkah untuk mencapai keselamatan daripada hukuman dan mendapat syurga. Secara zahirnya konsep taubat dalam aspek penyesalan dan memohon pengampunan dosa dari sudut pandangan Islam dan Kristian kelihatan seakan sama. Namun perbezaan terserlah pada aspek matlamat dan perlaksanaan taubat. Islam menetapkan aspek adil dalam bertaubat selari dengan fitrah manusia dan kunci keimanan kepada konsep ketuhanan yang Maha Esa. Manakala agama Kristian meletakkan taubat sebagai kunci keimanan kepada Tuhan tanpa mampu memberi jaminan keadilan terhadap manusia dan hak-haknya. Justeru, artikel ini menganalisis perbandingan konsep taubat dari perspektif Islam dan Kristian. Kaedah perbandingan kontekstual digunakan dalam penulisan ini. Dapatan kajian menjelaskan wujudnya perbezaan
\end{abstract}

\footnotetext{
Makalah ini adalah versi kemaskini dan penambahan terhadap kertas kerja yang dibentang dalam Seminar Pemikiran Islam IV, Jabatan Akidah dan Pemikiran Islam, Akademi Pengajian Islam, Universiti Malaya, 9-10 Disember 2015.
} 
pengaplikasian taubat dan keadilan dalam Islam serta ketidakseimbangannya dalam Kristian.

Kata kunci: Taubat, keadilan, fitrah manusia, Islam, Kristian.

\begin{abstract}
The value of repentance is emphasized in both religions of Islam and Christianity and it is regarded as the method of purification of the soul. Both religions consider the repentance as a liaison between God and man and it is a way to achieve salvation. Apparently, the concept of repentance in the aspect of remorse and forgiveness of sins reflected in much of the religion of Islam is found similar to the concept of repentance found in the religion of Christianity. However, there are apparent differences in term of the goals and the implementation aspects of repentance. Islam sets the aspects of justice in repentance in line with the human nature and the divine concept. While, Christianity puts the repentance as the key to faith in God without being able to assure justice to human beings and their rights. Therefore, the present paper examines the concept of repentance from the Islamic viewpoint and the Christianity perspective. The contextual comparison method was used in this study. The findings show the significant differences of the application of repentance and justice between Islam and Christianity and there are practical disparities in Christianity.
\end{abstract}

Keywords: Repentance, justice, human nature, Islam, Christianity.

\title{
Pendahuluan
}

Taubat menjadi kaedah utama proses penyucian jiwa dalam ajaran Islam dan Kristian bagi mewujudkan hubungan antara manusia dengan Tuhannya. Upaya melestarikan hubungan manusia dengan Tuhan perlu kepada tindakan berasaskan taubat dalam bentuk spiritual 
yang didukung oleh peranan fizikal manusia. Rohani yang suci bersih dan telus melahirkan keyakinan akan wujudnya kasih sayang Tuhan serta limpahan kurniaNya yang menjanjikan keselamatan ${ }^{1}$ dan kesejahteraan di dunia mahu pun di akhirat.

Justeru makalah ini akan merincikan konsep taubat yang ditekankan dalam agama Islam dan Kristian menurut perspektif masing-masing untuk melihat titik persamaan dan perbezaan antara keduanya.

\section{Definisi Taubat menurut Islam}

Etimologi taubat adalah perkataan bahasa Arab al-tawbah (التَّوَبَةُ) yang berasal dari akar kata t-w-b (ت و ب) dan ditukar menjadi kata kerja tāba (تاب) dengan

${ }^{1}$ Dalam agama Kristian, keselamatan atau salvation merupakan tujuan utama agama. Malah Gereja Katolik mendakwa keselamatan hanya terdapat di dalam gereja melalui Christ (Solus Christus) iaitu keimanan terhadap Jesus disalib kerana menebus dosa manusia. Justeru mereka mendakwa di luar gereja tiada keselamatan (exstra ecclesiam nulla salus) sehingga berlangsungnya Majlis Vatikan Kedua (Second Vatican Council) pada tahun 1962 hingga 1965 yang menyaksikan Gereja Katolik mula bertolak ansur terhadap penganutpenganut agama lain di samping Protestan. Pada hakikatnya, jaminan keselamatan hanya ada pada Islam sebagai sebuah agama yang selamat dan sejahtera. Merujuk kepada akar kata aslama, yuslimu, islāman, Islam menurut Ibn Manzūur bererti selamat, sejahtera, damai dan sebagainya. Perihal ini lebih kukuh dengan hadis Nabi SAW dalam pelbagai riwayat di antaranya Muhammad Ibn Ismā'īl alBukhārī al-Ja'fī, Șahīh al-Bukhārì, ed. Muștafā Dīb al-Bughā, cet.5 (Beirut: Dār Ibn Kathïr, 1993), 9 (Kitab Bad'u al-Wahy, Bab Kayf Kāna Bad'u al-Waḥy ilā Rasūlillāh, no. hadis 7); Muslim bin alHujjaj al-Qushayri al-Naysābūri, Șahih Muslim (Riyadh: Bayt alAfkār al-Dawliyyah, 1998), 737 (Bab: Fī Ghazwah Hunayn, Kitab al-Jihād wa al-Sayf, no. hadis 1775); di mana baginda bersabda: "Aslim Taslam". Ini bermakna sesiapa yang masuk Islam, dia akan selamat. Lihat Sayyid Quțb, Tafsīr fi Zilāl al-Qur'ān, terj. Yusoff Zaky Hj Yaacob (Kuala Lumpur: Pustaka Darul Iman, 2010), 3:337; Osman, Ahmad Sabri, Mohd Farid Mohd Sharif dan Raihaniah Zakaria, "Konsep Keselamatan dan Kebenaran menurut Islam dan Pluralisme Agama: Analisis menurut Pandangan Ismail Raji alFaruqi," Jurnal Intelek 8:1, (2015). 
menggantikan huruf wau kepada alif. Kamus-kamus Arab ${ }^{2}$ menukilkan perkataan tā-ba, yatū-bu, taw-batan تَوَبَةُّ - ينوب taubat dengan pelbagai makna, di antaranya 'āda, rajā'a, dan anāba yang kesemuanya membawa maksud kembali, sama ada kembali kepada Tuhan atau kembali kepada manusia. Ibn Manz̄ūr dan Fayrūz Ābādī sepakat menyatakan taubat bermaksud kembali kepada Allah daripada dosa, kembali kepada Allah sahaja, atau kembali mentaati selepas berbuat dosa, atau bermaksud kembali daripada dosa. ${ }^{3}$

Istilah taubat juga merujuk kepada tindakan Allah memberi ampun, menerima, mengembalikan atau kembali ke arah manusia dalam bentuk rahmat dan kasih. ${ }^{4}$ AlFayyūmī, al-Asfahāni, Ibn Fāris, dan al-Zamakhshari telah memberikan pengertian taubat Allah ke atas hamba bermaksud Allah telah kembali kepada hambaNya dengan keampunan. $^{5}$ Putaran ini adalah peralihan daripada kemurkaan Allah kepada rahmatNya, penolakan kepada penerimaan, atau daripada hukuman kepada keampunan.

Dalam penulisan Arab, taubat yang merujuk kepada taubat Allah lazimnya diiringi dengan kata sendi taba

${ }^{2}$ Di antaranya Aḥmad bin Fāris ibn Zakaryya al-Qazwīini, Mu jam Maqāyis al-Lughah (Beirut: Dar Ihya' al-Turath al-'Arab̄̄, 2001), 158; Muhammad ibn Mukarram ibn Manzūr, Lisān al-'Arab, Cet.3 (Beirut: Dar Ihyā al-Turāth al-'Arabī, 1999), 2:61; Muhammad bin Ya'qūb Fayrūz Ābādī, al-Qāmūs al-Muhịt, cet.6 (Beirut: Muassasah al-Risālah, 1998), 62; Al-Munazzamah al-'Arabiyyah li al-Tarbiyyah wa al-Thaqāfah wa al-'Ulūm, al-Mu'jam al-'Arabì al-Asasì: li alNātịīin bi al- 'Arabiyyah wa Muta 'allimiha (t.t.p: Lidurus, t.t), 205.

${ }^{3}$ Ibn Manz̄ūr, Lisān al-'Arab, 2:61; Fayrūz Abādī, al-Qāmūs al-Muhīt, 62.

${ }^{4}$ Ibid.; Ibn Manẓūr, Lisān al- 'Arab, 2:61.

${ }^{5}$ Aḥmad bin Muhammad bin 'Alī al-Fayyūmī, al-Misbāh al-Mun̄̄r fi Gharīb al-Sahih al-Kabìr li al-Rafi 'ì (Beirut: Maktabah al-'Ilmiyyah, 1985), 78; al-Rāghib al-Asfahānī, al-Mufradāt Cet.3 (Lubnan: Dar alMa'rifah, 2001), 72; Ibn Fāris, Mu'jam Maqāyis al-Lughah, 1:357, Mạ̣mud ibn 'Umar ibn Aḥmad al-Zamakhshari, Asās al-Balāghah (Beirut: Al-Kutub al-'Ilmiyyah, 1998), 40. 
'ala.$^{6}$-Ayat ini jelas menyatakan tindakan Allah menerima taubat hambaNya dengan kelembutan, memberi taufik serta memudahkan manusia sesuai dengan nama dan sifatNya al-Tawwāb. Menurut Imam al-Qushayri, al-Tawwāb bermaksud "yang menerima taubat dan memberi maaf kepada makhluk yang berdosa."7

Sifat Allah al-Tawwāb yang termaktub di dalam alQuran memberi maksud Allah itu sangat banyak taubatNya dan banyak pula penerimaanNya pada taubat hamba kerana ramai yang bertaubat kepadaNya atau kerana Allah telah memberi ilham kepada para hambaNya agar bertaubat. ${ }^{8}$ Manakala penggunaan kata sendi 'ila' ' merujuk kepada taubat manusia banyak termaktub di dalam ayat-ayat al-Quran'.

Perbahasan di atas menunjukkan wujud perkongsian lafaz taubat hamba dan taubat Allah SWT dalam konteks taubat. Jika kata taubat dinisbahkan kepada hamba, maka taubat bermaksud kembali kepada Tuhan daripada kemaksiatan. Manakala taubat sebagai sifat Allah ialah Allah kembali kepada hamba dengan rahmatNya dan keampunan.

Selain bermaksud kembali, kata taubat juga mempunyai makna lain iaitu sesal atau kecewa. Kamus

${ }^{6}$ Sūrah al-Baqarah; 37, 54, 160, 187; al-Nisā': 17; al-Mā‘idah: 39, 71, al-Tawbah: 117, 118; Țāhāa: 122, al-Mujādilah: 13, al-Muzammil: 20.

7 'Abd al-Karim ibn Hawazin al-Qushayri, al-Tahbir fi Tazkir, terj. Tafsir al-Sufi (Selangor: Wholesale Mart Business Point,t.t), 168.

${ }^{8}$ Fakhr al-Dīn Muhammad ibn `Umar, al-Tafsir al-Kabī (Beirut : Dar al-Fikr, 1993-1994), 3:22; 'Abdullah Muhammad bin Ahmad AlQurțūbī, al-Jāmi ' li Ahkam al-Qurān, ed. Sālim Mușțafā al-Badrī, (Beirut: Dar al-Kutub al-'Ilmiyyah, 2000), 1: 325; Maḥmud ibn `Abd Allah al-Alūșī al-Baghdāḍi, Rūh al-Ma ānì fi Tafsìr al-Qur'an al`Azìm wa al-Sab' al-Mathānī (Beirut: Idārat al-Tiba`ah alMuniriyah, t.t), 1: 237-238; Muhammad al-Ṭāhir ibn `Āṣhūr, Tafsìr al-Tahrīr wa al-Tanwīr (Beirut: Muassasah al-Tārikh, 2000), 1: 439.

${ }^{9}$ Sūrah al-Baqarah: 54; al-Mā'idah: 74; al-Furqān:71; Hūd: 3, 52, 61, 90; al-Nūr: 31. 
Dewan menukilkan taubat sebagai penyesalan akan dosa (perbuatan jahat dan lain-lain) dan berazam untuk tidak akan berbuat dosa (jahat) lagi atau kembali kepada Tuhan (dengan meninggalkan perbuatan dan lain-lain yang dilarang dan membuat apa-apa yang disuruh). ${ }^{10}$ Pengertian ini ada signifikannya tentang makna dasar $t-w-b$ iaitu $n-d$ $m$ bererti penyesalan sebagaimana hadis riwayat Ibnu Mājah, Ibn Hịbān dan al-Hākim bahawa Nabi Muhammad SAW bersabda: الندم توبة

Namun sebahagian ahli leksikografi seperti Khalīl 'Ayn, al-Zamakhsharī, Ibn Sīda, Fayrūz Ābādī dan Fayyūmī tidak mendefinisikan taubat dengan makna nadam yang juga bererti kekesalan, kesedihan dan kekecewaan. Makna penyesalan itu lebih banyak digunakan dalam pendefinisian terminologi taubat, seperti mana pentakrifan al-Rāghib al-Isfahānī dalam kitabnya Mufradāt Alfāz al-Qur'ān dan al-Ghazālī dalam Ihyā' 'Ulūm al-Dinn bahawa taubat adalah suatu penyesalan. ${ }^{12}$ Oleh itu, al-Fayyūmī cenderung memberikan pengertian aqlā'a untuk kata 'tāba yatūbu tawban' dan matāban iaitu perbuatan mencabut daripada dosa orang yang bertaubat. Manakala taubat Allah 'tāba 'alā Allāh' ialah memberikan keampunan dan menyelamatkannya daripada perkaraperkara maksiat. ${ }^{13}$

${ }^{10}$ Hajah Noresah Baharom, ed. Kamus Dewan (Kuala Lumpur: Dewan Bahasa dan Pustaka, 2010), 1616.

11 Lihat Muhammad bin Yazid al-Qazwini, Sunan Ibn Majah (Riyadh: Maktabah al-Ma'ārif, t.t), 70 (kitab zuhud, bab zikr al-tawbah, no.hadis 4252); Aḥmad ibn Muḥammad ibn Hanbal al-Shaybān̄̄, Musnad Imām Aḥmad Ibn Hanbal, (Riyadh: Dar al-Afkār alDawliyyah, 1988), 1:376-[307] (Musnad al-Mukathirin, Musnad 'Abdillah ibn Mas'ūd 1:376. no.hadis 3568).

${ }^{12}$ Al-Rāghib al-Asfahān̄̄, Mufradāt fi Gharib al-Qur'ān, 169, dan Abū Hāmid Muhāmmad bin Muḥammad al-Ghazālī, Ihyā' 'Ulūm al-Dīn, ed. Al-Ṣiḥhạât al-Ṭaḥhān, 'Abdullah al-Minshāri (Mansurah: Maktabah al-Īmān, 1996), 4:5.

${ }^{13}$ al-Fayyūm̄̄, al-Misbah al-Munīr, 30. 
Dalam ilmu semantik, penggunaan taubat juga selari dengan perkataan inaba, awba dan 'awd selain ruju'. Ketiga-tiga lafaz ini memberi maksud taubat manusia terhadap tuhan, iaitu kembali daripada perlanggaran dosa kepada ketaatan. ${ }^{14}$ Walau bagaimanapun, kata 'awd dan $a w b a$ terkadang digunakan dengan penekanan berbeza merujuk kepada perkara bukan agama seperti kembali pulang ke rumah dan sebagainya. Sementara inaba pula yang berakar kata $n-w-b$ lazim ditakrifkan dalam konteks bahasa sebagai kepatuhan kepada tuhan dengan maksud 'mengganti kembali'. ${ }^{15}$ Begitu juga munīb seperti $t \bar{a}$ 'ib (isim fá 'il dari taba), ialah individu yang kembali kepada Tuhan dengan patuh ${ }^{16}$ dan anaba ${ }^{17}$ menunjukkan orang yang bertaubat kerana takut akan azab Allah.

Menyentuh sudut terminologi, al-Quran dan alSunnah menjadi asas untuk memahami istilah taubat sehingga melahirkan pelbagai perbahasan dalam ilmu tafsir, hadis, tasawwuf, ilmu kalam dan ilmu fiqh. Ibn Kathîr, ${ }^{18}$ al-Alūsi' ${ }^{19}$, al-Rāghib al-Isfahān̄i, Ibn 'Ashūr, ${ }^{20}$ Sayyid Quṭ dan al-Zuhayli pada zahirnya memberikan definisi berbeza ketika mentafsirkan ayat-ayat taubat di

${ }^{14}$ Ibn Manzūr, Lisān al-'Arab, 2:61, 'Alī ibn Ismā'ìl ibn Sīdah, alMuhkam wa al-Muhit al-A żam fi al-Lughat (Kaherah: Sharikah Maktabah wa-Mațba`ah Muștafā al-Bābī al-Ḥalābī, 1958), 9:541542.

${ }^{15}$ Ibid, $14: 318$.

${ }^{16}$ Ibid.

17 Al-Quran melestari makna taubat dalam perkataan anaba dengan kata terbitan pelbagai di dalam surah al-Ra'd:13:27; Luqmān:31:15; Șād: 38:24; al-Zumar:39:8, 17, 54; al-Mumtahinah: 60:4; Hūd: 11:75 \& 88; al-Shūrā:42:10 \& 13; Ghāfir: 40:13; Saba: 34:9; Qāf:50:8 \& 33; al-Rūm: 30:31 \& 33. Lihat Muhammad Fu'ad `Abd al-Bāqi, Mu `jam Mufahras fì Alfāz al-Qur'ān (Kaherah: Dār al-Hadis, 2007), 892.

18 Isma'īl ibn Kathīr al-Dimashqi, Tafsīr al-Qur'ān al-'Az̄̄m (Giza: Mu'assasah Qurtubah, 2000), 2:135, \& 132 dan surah al-An'ām ayat 54, 14:60.

${ }^{19}$ Al-Alūsī al-Baghdādī, Rūh al-Ma ānì fi Tafsìr al-Qur'an, 25: 36.

${ }^{20} \mathrm{Ibn} `$ Āshūr, Tafsìr al-Tahrīir wa al-Tanwīr, 18:75. 
dalam al-Quran. Namun hakikatnya pentafsiran mereka terhadap takrif taubat secara umum tidak terkeluar daripada maksud kesedaran individu terhadap keburukan dosa, berhenti daripada melakukannya kerana Allah Ta'ala, disertai penyesalan serta azam untuk tidak mengulanginya, di samping mengerjakan ketaatan dan kebajikan dalam memenuhi hak Allah dan manusia.

Dalam konteks ilmu Fiqh, taubat cenderung dirujuk kepada penyesalan dan pencabutan dosa maksiat yang dilakukan, berserta azam untuk tidak mengulanginya semula sekalipun berkemampuan melakukannya dan bukan disebabkan rasa takut mendapat mudarat kepada badan dan harta akibat perbuatan maksiat. ${ }^{21}$ Pada sisi lain, taubat juga dimaksudkan dengan kembali daripada jalan yang bengkok kepada jalan yang lurus, ${ }^{22}$ manakala M.Shokry menukilkan ulama Fiqh bersetuju tiga perkara dalam bertaubat yang melibatkan elemen mental dan material iaitu penyesalan, azam untuk berhenti daripada melakukan dosa selama-lamanya dan mengerjakan amalan baik..$^{23}$

Definisi ini secara umumnya tidak berbeza dengan pengertian taubat dari perspektif ilmu tasawwuf. Para $\mathrm{Sufi}^{24}$ cenderung mengumpulkan tiga perkara yang perlu

${ }^{21}$ Al-Ba'li dalam Sa`ādī Abu Jaib, al-Qāmūs al-Fiqhī, cet.3 (Damsyik: Dar al-Fikr,1988), 50

22 Wizārat al-Awqāf al-Kuwaytiyyah, al-Mawsū'ah al-Fiqhiyyah alKuwaytiyyah (t.tp: t.p, t.t),11-20:615.

${ }^{23}$ M. Shokry el-Dakkak, Repentance as a Defence: Comparative Study Under Islamic Law, Common Law and Continental Law (Kuala Lumpur: A.S Noordeen, 1994), 15.

${ }^{24}$ Al-Nawāwī, Riyāẹ al-S̄ālihīn (Beirut: Al-Maktabah al-Islāmiyyah, 1979), 10-11. Abd al-Qāsim `Abd al-Karīm al-Qushayrī, al-Risālah al-Qushayriyyah fì 'Ilm al-Tașawwuf (Kaherah: Dār al-Kutub alHadīthah, t.t), 254, al-Ḥārith bin Asad al-Muhāsibī, al-Tawbah, ed. Ábd al-Qādir Aḥmad 'Ațā (Kaherah: Dār al-Faḍilah, t.t), 51, Abū Hāmid al-Ghazāīī, Ihyā' 'Ulūm al-Dìn, 4:4 Muhammad bin Abī Bakr ibn Ayyūb Ibn Qayyim al-Jawziyyah, Madārij al-Sālikīn: Bayn Manāzil "Iyyāk Na'bud wa Iyyāk Nasta'īn, ed. Riḍwān Jāmi" 
ada untuk kembali kepada Allah iaitu penyesalan atas dosa, meninggalkannya pada masa sekarang, dan keazaman untuk meninggalkannya pada masa hadapan. ${ }^{25}$

Di antaranya al-Junayd dan al-Qushayri menyatakan taubat secara umumnya ialah meninggalkan dosa dalam segala bentuknya, menyesali dosa yang pernah dilakukan, dan bertekad untuk tidak melakukan dosa lagi. ${ }^{26} \mathrm{Al}-$ Muhāsibi turut menjelaskan bahawa penyesalan yang benar itu mampu menggegar jasad yang tumbuh daripada pengaruh benda haram, bukan semata-mata mengulangi lafaz penyesalan dengan lidah dan mereka-reka di hadapan manusia. ${ }^{27}$ Justeru kembali dalam istilah ahli sufi dijelaskan sebagai kembali kepada ketaatan dari semua bentuk kemaksiatan mahupun kembali dari nafsu kepada yang hak lagi benar. ${ }^{28} \mathrm{Al}$-Jurjāni juga senada menyatakan taubat adalah kembali kepada Allah dengan melepaskan ikatan yang mengekang hati untuk bangun maju memenuhi hak-hak Allah. ${ }^{29}$

Tuntasnya, pengertian taubat dirumuskan sebagai meninggalkan dosa dalam segala bentuknya, menyesali dosa yang pernah dilakukan, dan bertekad untuk tidak melakukan dosa lagi dan berlaku dalam dua hala; tidak terhad kepada tindakan satu arah sahaja dalam bentuk horizontal. Sebaliknya tindakan boleh berlaku dalam bentuk vertikal melalui taubat Allah kepada hambaNya

Riḍwān (Kaherah: Mu'assasah al-Mukhtār, 2001), 1:199, 1:313, Ibn Hajar al-'Asqalānī, Fatḥ al-Bārī, 11:106.

25 Al-Kayyalī, 'Asim Ibrāhīm, al-Qāmīs al-Ṣūfì (Lebanon: Books Publisher, 2011), 85.

${ }^{26}$ Al-Qushayrī, al-Risālah al-Qushayriyyah, 77 \& 254.

27 Al-Hārith bin Asad al-Muhāsibì, al-Tawbah, ed. 'Abd al-Qādir Ahmad 'Atțā' , (Kaherah: Dār al-Fadịilah, t.t), 52.

28 Anwār Fu'ād Abī Khazam, Mu jam al-Muștalahāat al-Sūfiyyah (Beirut: Maktabah Lubnān, 1993), 643

29 Sharif 'Alì bin Muḥammad al-Jurjānì, Kitāb at-Ta rī $\bar{f} a ̄ t$, cet. 3 (Beirut: Dār al-Kutub al-'Ilmiyyah, 1988), 70; Abī Khazam, Mu ‘jam al-Musțalaḥāt al-Sūfiyyah, 644. 
yang bermaksud Allah kembali berpaling kepada manusia melalui pengampunanNya.

\section{Konsep Taubat menurut Islam}

Kejadian manusia bersama fitrahnya yang suci memiliki kecenderungan alamiah terhadap kebenaran dan ketundukan kepada Allah. ${ }^{30}$ Pada masa yang sama manusia dikurniakan akal dan kemahuan yang menjadi asas kepada taklif dan balasan. ${ }^{31}$ Pun begitu, apabila manusia menyimpang dari kebenaran dengan melanggar perintah dan larangan merupakan dosa dan kemaksiatan ${ }^{32}$ yang dipandang sebagai kederhakaan.

Tindakan ini tentu sahaja merosakkan hubungan Allah dengan manusia kerana terjadi penyelewengan terhadap aturan agama. Justeru tindakan pemulihan bagi hubungan yang tercemar memerlukan amalan taubat dan sekaligus sebagai sarana untuk menghapuskan dosa serta mendapat keampunan dan syurga. ${ }^{33}$

\section{a. Hukum Bertaubat}

Hukum bertaubat merupakan satu kewajiban dalam agama Islam dan termaktub di dalam al-Quran dan hadis. Kewajipan bertaubat itu umum kepada semua manusia dalam segala keadaan tanpa ada pengecualian ${ }^{34}$.

Ayat berhubung taubat sama ada dalam bentuk ayat perintah $^{35}$ yang menunjukkan wajibnya taubat, atau disertakan dengan ancaman azab. ${ }^{36}$ Al-Quran menyelar orang yang enggan bertaubat sebagai zalim kerana tidak

${ }^{30}$ Yasien Mohamed, Insan Yang Suci: Konsep Fithrah dalam Islam, terj. Masyhur Abadi (Bandung: Penerbit Mizan, 1997),17.

${ }^{31}$ Sayyid Quṭb, Fī Zilāl al-Qur'an, 1:59.

32 Al-Fayrūz Ābādī, Muhammad bin Yàqūb, Al-Qāmūs al-Muhīt, 1312; Majma' al-Lughah al-'Arabiyyah, al-Mu'jam al-Wasīt, (t.t), 2:612.

${ }^{33}$ Surah al-Tahrim 66:8.

${ }^{34}$ al-Ghazāli, Ihyā' 'Ulūm al-Dīn, 4:12

${ }^{35}$ Lihat surah al-Baqarah 2:54; Hūd 11: 3, 52, 61 dan 90; al-Nūr 24:31 dan al-Tahrim 66:8.

${ }^{36}$ Lihat al-Zumar, ayat 54. 
menjalankan perkara hak. Manakala Mufassir telah menjadikan gelaran ini sebagai dalil untuk menghukum haram bagi yang meninggalkan taubat. Terdapat juga ayat al-Quran dan Hadis memberi isyarat akan kewajiban bertaubat serta kepentingannya, galakannya dan seruan menyegerakannya. ${ }^{37}$ Firman Allah Ta'ala dalam surah alNūr 24:31:

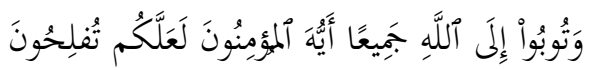

Terjemahan: ... dan bertaubatlah kamu sekalian kepada Allah, wahai orang-orang yang beriman, supaya kamu berjaya.

Manakala dalam Hadis riwayat Muslim pula menyebutkan sabda Rasulullah s.a.w ${ }^{38}$ :

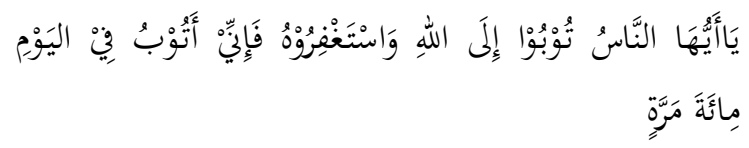

Terjemahan: Wahai sekalian manusia, bertaubatlah kepada Allah, sesungguhnya aku bertaubat kepada Allah dalam sehari sebanyak 100 kali.

Ayat al-Quran di atas menunjukkan dua perkara mengenai taubat iaitu kewajipan bertaubat yang dikaitkan dengan kejayaan. Manakala hadis pula mengisyaratkan akan pentingnya taubat yang diwajibkan kepada manusia sehinggakan Nabi Muhammad SAW yang terpelihara daripada dosa adalah individu yang paling banyak bertaubat. Oleh itu setiap Muslim diwajibkan bertaubat

${ }^{37}$ Al- Bayāti, Munīr, Mawsū'ah al-Muslim fì al-Tawbah wa al-Tarqī fì Madārij al-Īmān, Cet.2 (Jordan: Dar al-Nafā'is, 2007), 1:255 \& 267. Surah al-Zumar ayat 54 (...sebelum kamu didatangi azab;...) juga sebagai isyarat taubat itu perlu dilakukan dengan segera kerana manusia tidak pernah tahu bila ajal maut menjemputnya.

38 Muslim, Șahịh Muslim, 1084 (Kitāb al-Dhikr wa al-Du'ā', Bab Istiḥbāb, No. Hadis 2702) 
kepada Allah dan hendaklah dilakukan dengan kadar segera $^{39}$ serta berulang kali. Al-Ghazāli menyatakan bahawa dosa yang dilakukan berterusan akan menyebabkan hati gelap dan keras serta membawa kepada hilangnya keikhlasan dalam beribadat. Maka taubat diperlukan sebagai asas untuk penerimaan ibadat dan penyucian hati. ${ }^{40}$

\section{b. Ciri-Ciri Taubat.}

Islam menggesa penganutnya melakukan taubat nasuha sebagaimana termaktub di dalam al-Quran yang bermaksud "...Bertaubatlah kamu kepada Allah dengan Taubat Nasuha...". Ibn Jarir, Ibn Kathïr ${ }^{41}$ dan Ibn Qayyim ${ }^{42}$ mengertikan 'nasuha' sebagai taubat daripada dosa dengan sepenuh hati dan tidak melakukannya lagi. Al-Ghazāli pula menyatakan nasuha bererti bersih sematamata kerana Allah, terlepas dari segala kecurigaan. ${ }^{43}$ Justeru itu, fuqaha' menafikan bentuk taubat yang didasari oleh rasa takut kepada sesuatu selain Allah seperti berhenti melakukan dosa kerana mengelak dari ditimpa kemudaratan terhadap badan atau harta pelakunya. ${ }^{44}$ Taubat seperti ini belum dikatakan sempurna keikhlasannya kepada Allah.

Justeru untuk menjalani taubat nasuha, majoriti ulama telah meletakkan syarat-syarat ${ }^{45}$ sah taubat bagi memastikan taubat yang dilakukan diterima Allah. Di antaranya, al-Qushayri mengemukakan tiga syarat taubat iaitu menyesali dosa yang telah dilakukan, meninggalkan

${ }^{39}$ Al-Ghazālì, Ihyā' 'Ulūm al-Dīn, 4:10

${ }^{40}$ Al-Ghazāli, Minhaj al- 'Abidin, 63.

41 Ibn Kathīr, Abū al-Fidā' Ismā'il, Tafsīr al-Qur'ān al-'Azīm, ed. Muștafa al-Sayyid Muhammad (Giza: Mu'assasah Qurtubah, t.t), 14: 61-62

${ }^{42}$ Ibn Qayyim al-Jawziyyah, Madārij al-Sālikīn, 1: 261;

${ }^{43}$ Al-Ghazālì, Ihyā 'Ulūm al-Dìn, 4:6.

${ }^{44}$ Wizārat al-Awqāf al-Kuwaytiyyah, 11:615.

45 Sebahagian ulama Kalam menamakan syarat taubat sebagai rukun taubat. Lihat al-Bayāti, Mawsū 'ah al-Muslim fi al-Tawbah, 1:298. 
dosa dan berjanji agar tidak mengulangi dosa tersebut. ${ }^{46}$ Pandangan ini dipersetujui oleh beberapa ulama lain seperti al-Ghazāli, Herawi dan al-Qaraḍāwi. ${ }^{47}$

Pendapat ini juga diperkukuh dengan ayat al-Quran dalam surah Āl-'Imrān ayat 135 yang mengandungi ketiga-tiga syarat di atas yang bermaksud: "Dan juga orang-orang yang apabila melakukan perbuatan keji atau menganiaya diri sendiri, mereka segera ingat kepada Allah lalu memohon ampun akan dosa mereka dan sememangnya tidak ada yang mengampunkan dosa-dosa melainkan Allah dan mereka juga tidak meneruskan perbuatan keji yang mereka telah lakukan itu, sedangkan mereka mengetahui (akan salahnya dan akibatnya)".

Sejajar dengan itu, al-Nawāwì menegaskan ketigatiga syarat tersebut perlu wujud bagi dosa yang berhubung dengan hak Allah. Manakala dosa bersangkutan dengan hak manusia, ditambah dengan syarat mengembalikan harta atau kezaliman kepada mereka yang dizalimi. ${ }^{48} \mathrm{Di}$ samping itu, al-Ghazāli menekankan amalan taubat yang dituntut perlu didasari atas tiga unsur penting iaitu ilmu berupa pengetahuan terhadap kesalahan yang dilakukan; hati yang menyesal dengan tekad serta keinginan untuk tidak mengulangi kesalahan; dan unsur praktikal melalui amal kebajikan yang dijalankan agar hakikat taubat terpenuhi. ${ }^{49}$ Sementara al-Qurțūbi menyatakan hakikat taubat yang benar dan ikhlas itu perlu melalui penyesalan hati, istighfar lisan dan mencabut segala kejahatan daripada badan dengan keyakinan tidak mengulanginya lagi. ${ }^{50}$

\footnotetext{
${ }^{46}$ Al-Qushayrī, al-Risālah al-Qushayriyyah, 179.

47 Yūsuf al-Qaraḍāwī, al-Tawbah ila Allāh (Kaherah: Maktabah Wahbah, 1998), 53.

${ }^{48}$ Al-Nawawì, Riyāẹ al-Sālihīn, 17

${ }^{49}$ Al-Ghazālī, Ihyyā' 'Ulūm al-Dìn, 4:4.

${ }^{50}$ Al-Qurțūbì, al-Jāmi ‘ li Ahkam al-Qur'ān, 18:129; Șiddīq bin Hasan bin 'Ali al-Hussayn al-Qinūji al-Bukhāri, Fath al-Bayān fí Maqāṣid al-Qur'ān, (Beirut: al-Maktabah al-'Așriyyah, 1992), 14:217-218.
} 
Di samping tiga syarat yang telah dikemukakan, alJuwayni menambah satu lagi syarat selain menyesal, iaitu berhenti lakukan dosa dan berazam untuk tidak ulanginya. Menurut beliau, jika kesalahan atau dosa dilakukan melibatkan penzaliman hak sesama manusia, pelepasan, penyelarasan atau penggantian terhadap hak individu yang dizalimi menjadi satu keperluan. Hal ini kerana setiap manusia telah dipertanggungjawab memelihara maqasid syariah yang lima untuk kelestarian kehidupannya di muka bumi.

\section{c. Matlamat Taubat}

Di antara manifesto kewajipan bertaubat di dalam alQur'ān ${ }^{51}$ ialah untuk mendapatkan kejayaan "... dan bertaubatlah .., supaya kamu berjaya"; dan menjadi harapan untuk penghapusan dosa dan pengurniaan syurga, "...mudah-mudahan Tuhan kamu akan menghapus kesalahan-kesalahanmu dan memasukkan kamu ke dalam syurga yang mengalir di bawahnya sungai-sungai.." Justeru keampunan daripada Allah SWT yang membawa kepada penghapusan dosa dan pengurniaan syurga adalah antara kejayaan yang akan diperolehi oleh individu yang bertaubat.

Imam al-Ghazāli berpendapat ketaatan dan penerimaan ibadat menjadi sebab diwajibkan taubat ${ }^{52}$ supaya dengannya dosa terhapus melalui keampunan Ilahi dan melayakkannya masuk syurga. Sekalipun janji masuk ke dalam syurga hanya ada dalam pengetahuan Allah, namun jaminan ini sudah cukup memberi ketenangan pada hati dan minda manusia.

\section{d. Kuasa Pengampunan Taubat.}

Meneliti ayat 8 dalam surah al-Tahrim mengenai perintah taubat kepada Allah, terdapat selepasnya penekanan bahawa Allah SWT sahaja yang layak menghapuskan

\footnotetext{
${ }^{51}$ Surah al-Nūr ayat 31 dan surah al-Tahrim ayat 8 .

${ }^{52}$ Al-Ghazālì, Minhāj al- 'Ābidīn, 63.
} 
kesalahan dan mengampunkan dosa-dosa individu yang benar taubatnya yang bermaksud, ".....mudah-mudahan Tuhan kamu akan menghapus kesalahankesalahanmu....,53 Ayat ini merupakan penegasan bahawa kuasa pengampunan dan penghapusan dosa adalah hak milik mutlak Allah. Perkara ini sekaligus menafikan penglibatan makhluk apapun dalam urusan pengampunan. ${ }^{54}$

\section{e. Proses dan Perlaksanaan Bertaubat}

Dalam konteks ayat perintah bertaubat di dalam al-Quran seringkali juga ditemui perintah diiringi dengan suruhan beristighfar $(ا س ت غ ف ر)^{55}$ dan memohon keampunan. ${ }^{56}$ Kurang memahami konteks ayat di dalam al-Quran memungkinkan timbul salah faham ketika mengamalkan taubat. Tanggapan bahawa taubat itu ialah pengampunan dan meminta ampun itu pula adalah bertaubat telah menjadikan ucapan istighfar (astaghfirulläh) dan amalan berwirid istighfar selepas solat dijadikan sandaran telah melakukan taubat setiap hari. Hal ini tentunya belum menepati maksud taubat yang digariskan Islam.

Ahli sufi seperti al-Makki, al-Sahl dan Ibn 'Ata' cenderung menyatakan taubat yang benar harus dimulakan dengan istighfar yang diakhiri dengan taubat. Istighfar adalah permohonan ampun kepada Allah daripada segala dosa. Al-Makki menukil pendapat Sayyidina Ali dan Ibn 'Abbas akan perihal pentingnya istighfar dalam taubat ini, di samping menyatakan penjelasan al-Sahl tentang perlunya al-istijābah (memohon ampun) dan al-inābah (penggantian) dalam istighfar meliputi amalan zahir dan

53 Tafsir Pimpinan Ar-Rahman kepada Pengertian Al-Qur'ān (Malaysia: Darulfikri, t.t), 1534.

${ }^{54}$ Al-Qurțūbì, al-Jāmi ‘ li Aḥkam al-Qurān, 28:129.

${ }^{55}$ Istighfār atau maghfira dari akar kata gh-f-r ( غ ف) dengan maksud "melindungi" atau menunjukkan sesuatu yang tertutup. Lihat Ibn Manzūr, Lisān al-' Arab, 10:19

${ }^{56}$ Di antaranya surah Hūd ayat 52, 61 dan 89. 
batin yang diakhiri dengan țāwbāḥ. ${ }^{57}$ Pendapat ini senada dengan pandangan Ibn 'Ata' yang menyatakan taubat hanya terdapat dua jenis iaitu al-inābah dan al-istijābah.

Kalangan mufassirin menyatakan wujudnya perbezaan di antara taubat dan permohonan ampun atau istighfar. Di antaranya al-Rāzi menukilkan permohonan keampunan Tuhan daripada dosa-dosa adalah pendorong kepada amalan bertaubat, justeru kedua-duanya dituntut kerana taubat adalah pelengkap bagi permohonan ampun. ${ }^{58}$

Istighfar yang disertai dengan perasaan sesal dan azam untuk berhenti daripada dosa adalah taubat yang benar. Manakala istighfar semata-mata tanpa rasa sesal dan azam berhenti lakukan dosa hanya menjadi doa permohonan ampun semata. ${ }^{59}$ Proses taubat juga perlu berlaku serentak antara tindakan berhenti melakukan dosa, penyesalan terhadap dosa yang telah dilakukan dan azam untuk tidak melakukannya lagi di masa akan datang. Segala bentuk tindakan tersebut memungkinkan taubat diterima dan penerimaan taubat tersebut akan membawa kepada pengampunan Allah dan rahmat-Nya. Hal ini merupakan salah satu maksud taubat Allah Ta'ala.

Al-Rāzi turut menghuraikan pengertian berhenti melakukan dosa dan maksiat itu menuntut seorang hamba taat kepada semua perintah Allah. Perintah ini meliputi maksud mengerjakan suruhan tanpa mengabaikannya dan menjauhi setiap perkara yang dilarang serta istiqamah dalam mengamalkan kebaikan.

Manakala penyesalan atau kata $n-d-m$ juga sering disebut di dalam al-Qur'ān dan digunakan untuk tujuan

57 Abū Țālib al-Makkī, Qūt al-Qulūb fi Mu`amalah al-Mahbub waWasf Țarīq al-Murìd ila Maqām al-Tawhìd (Mesir: al-Maṭbàah alMaymaniyyah, 1990), 1:339.

${ }^{58}$ Fakhr al-Rāzí, al-Tafsìr al-Kabīr, cet. 3 (Beirut: Dār Ihyā' al-Turāth al-'Arabi, 1999), 17:315, lihat Surah Hūd 11:3.

59 Al- Bayāti, Mawsū'ah al-Muslim fi al-Tawbah, 2: 947. 
peringatan akan azab Allah SWT. Penyesalan ini melambangkan kekecewaan yang bakal diperolehi oleh manusia akibat perbuatan dosa yang dilakukannya. Justeru penyesalan lazimnya terungkap melalui perasaan sedih, dukacita dan pengakuan kepada Allah atas ketelanjuran dan dosa. Keadaan ini akan melahirkan hati yang sentiasa ingat dan takut kepada Allah serta memohon agar dosa diampunkan, dihapuskan catatan kejahatan dan bentuk balasan seksa yang dijanjikan bagi pelaku dosa. ${ }^{60}$

Ibn 'Arabi ketika mentafsirkan maksud menyesal dalam ayat 31 surah al-Mā'idah, “...Kerana itu menjadilah dia dari golongan orang-orang yang menyesal" menjelaskan penyesalan diterima jika menepati syarat-syaratnya iaitu menyesal kerana takut atau malu kepada Allah dan bukan disebabkan perkara lain; wujudnya rasa penyesalan yang sentiasa berterusan; dan penyesalan terhadap perkara yang lalu dengan syarat berazam tidak melakukannya lagi di masa akan datang. ${ }^{61}$

Senada dengan ini, al-Muhāāibì telah menggariskan dua elemen penting seiring dengan amalan bertaubat iaitu iman yang telus kerana Allah dan amal kebajikan yang juga ikhlas kerana Allah Taala. ${ }^{62}$ Menurut al-Muhāsibí, iman itu meliputi $i^{\prime} t i q a \bar{d} d$ dan amal perbuatan. ${ }^{63}$ Sementara perbuatan dalam iman ialah melakukan segala amalan yang wajib (fardu) dan segala cabang iman yang ada tujuh puluh lebih mengikut kadar kemampuan.

Gagasan ini ditekalkan dengan saranan para sarjana Muslim mengenai beberapa amalan praktikal sesuai dalam proses taubat di antaranya melakukan solat sunat taubat, zikir istighfar atau permintaan keampunan dengan hati dan

\footnotetext{
${ }^{60}$ Al- Bayāti, Mawsū'ah al-Muslim fi al-Tawbah, 1:307.

61 Muhammad ibn 'Abdullah, Ibn al-'Arabī, Ahkām al-Qur'ān, ed. Muḥammad 'Abd al-Qādir 'Ațā, cet. ke-3 (Beirut: Dār al-Kutub al'Ilmiyyah, 2003), 2:87-88.

62 Al- Muhāsibī, al-Tawbah, 52. Lihat surah al-Furqān 25:70 dan Maryam 19:60.

${ }^{63}$ Al- Muhāsibì, al-Tawbah, 52.
} 
gerakan lidah, memperbanyakkan solat-solat rawatib di samping soat-solat fardu, puasa dan memperbanyakkan amalan kebajikan di antaranya dengan amalan bersedekah. ${ }^{64}$ Manakala proses taubat yang melibatkan kezaliman terhadap sesama manusia, bagi individu yang bertaubat perlu memohon kemaafan daripada individu terbabit, serta berusaha mengembalikan semua hak yang telah diambil sebelumnya sama ada dengan cara sengaja atau pun tidak.

Dalam menangani sifat manusia yang tidak mungkin terlepas daripada melakukan kesalahan dan dosa, Islam melarang individu yang bertaubat mendedahkan kepada orang lain setiap kesalahan dan dosa yang pernah dilakukan. Hal ini kerana Allah telah menutupkan keaiban setiap hamba lantaran kasih dan rahmatNya. Ia merupakan sebuah metode pencegahan daripada penyebaran aib pelaku dosa yang pastinya akan menimbulkan fitnah dan mudarat. Oleh itu tidak wujud di dalam Islam konsep pengakuan dosa kepada manusia sepertimana yang diajarkan oleh sebahagian agama lain di dunia.

Tegasnya, proses bertaubat dalam Islam memerlukan gerak kerja hati (batin) dan anggota zahir yang selari agar menepati maksud dan metode bertaubat. Penekanan zahir dan batin ini sesuai dengan pembentukan individu yang terdiri daripada unsur jasmani dan rohani, fizikal dan spiritual. Justeru penglibatan yang seimbang di antara kedua-dua elemen tersebut dalam menjalani taubat mampu menghadirkan insan sebenar yang bersih jiwa dan raganya demi mencapai matlamat taubat berupa pengampunan Allah dan anugerah syurga.

\section{Definisi Taubat menurut Kristian}

Taubat dalam Kamus Oxford Dwibahasa Melayu dan Inggeris seerti dengan repentance atau regret yang juga

${ }^{64}$ Al-Ghazālì, Ihya' 'Ulūm al-Dìn, 4:45. 
membawa maksud sesal. ${ }^{65}$ Repentance atau repent adalah kata kerja dari bahasa Latin; paenitere membawa makna penyesalan. Menurut Jones Lindsay ${ }^{66}$ dan Mircea Eliade, paenitere juga merupakan upacara keagamaan yang membawa kepada perubahan tingkah laku seseorang, kemahuan, dan sikap, disertai dengan perasaan sedih dan penyesalan atas pelanggaran atau pencabulan pada masa lampau. ${ }^{67}$ Penyesalan ini mungkin saja diiringi dengan pengembalian sesuatu.

Manakala dalam Perjanjian Lama asal yang berbahasa Ibrani menjelaskan taubat sering diungkapkan dengan istilah Hebrew 'syurv', 'shuwb' atau בתשובה iaitu berputar, berbalik kembali. ${ }^{68}$ Taubat dalam tulisan Ibrani ini dilafazkan dengan sebutan 'shoob'. Dalam Perjanjian Lama Yesaya (31:6):

\begin{tabular}{|c|c|c|}
\hline $\begin{array}{l}\text { Bahasa Melayu } \\
\text { Indonesia }\end{array}$ & $\begin{array}{l}\text { Bahasa Hebrew } \\
\text { Tulisan Roman }\end{array}$ & $\begin{array}{c}\text { Bahasa \& } \\
\text { Tulisan Hebrew } \\
\text { Moden }\end{array}$ \\
\hline $\begin{array}{l}\text { Yesaya 31: 6: } \\
\text { Bertobatlah, hai } \\
\text { orang Israel, kepada } \\
\text { Dia yang sudah } \\
\text { kamu tinggalkan } \\
\text { jauh-jauh! }\end{array}$ & $\begin{array}{l}\text { Isaiah 31: } 6 \\
\text { ShVBV L'aShUr } \\
H^{\prime} y M Y Q V \text { SUrH } \\
B N Y \text { YShUr'aL. }\end{array}$ & $\begin{array}{l}\text { Isaiah 31: } 6^{69} \\
\text { סרובו בנשר העיקו }\end{array}$ \\
\hline
\end{tabular}

Perjanjian Baru asal yang berbahasa Greek pula mengungkapkan taubat dengan perkataan metanoia dan

65 Joyce M. Hawkins, Kamus Dwibahasa Oxford Fajar, ed.4 (Shah Alam: Oxford Fajar Sdn. Bhd. 2008), 287.

66 Lindsay Jones, Encyclopedia of Religion, ed.2 ${ }^{\text {nd }}$ (USA: Macmillan Reference, 2005), 7755.

67 Mircea Eliade, ed., The Encyclopedia of Religion (USA: Macmillan Library Reference, 1995), 11:337.

68 J.D Douglas, ed., Ensiklopedi Alkitab Masa Kini: The New Bible Dictionary, terj. (cet. ke-11, Jakarta: Yayasan Komunikasi Bina Kasih, 2011), 2:486, entri 'tobat'.

69 http://www.hebrewoldtestament.com/B23C031.htm\#V6, dicapai pada 17 Februari 2016. 
metanoeo atau metanoeite $e^{70}$ kira-kira 58 kali yang selalu diterjemahkan dengan bertaubat. $^{71}$ Makna dasar pertaubatan ialah 'berbalik' iaitu berbalik dari cara hidup yang jahat kepada Jesus Christ dan melalui Jesus kepada Tuhan. ${ }^{72}$ Perjanjian Baru dalam Matius 3:2: "Bertobatlah, sebab Kerajaan Sorga sudah dekat!" atau dalam versi

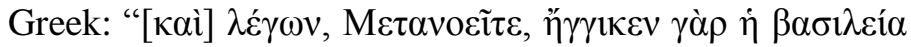
$\tau \tilde{\omega} v$ oủ $\rho \alpha \nu \tilde{\omega} v . "$

\begin{tabular}{|c|c|c|}
\hline $\begin{array}{c}\text { Alkitab Versi } \\
\text { Bahasa } \\
\text { Indonesia }\end{array}$ & $\begin{array}{c}\text { Alkitab Versi } \\
\text { Bahasa Malaysia }\end{array}$ & $\begin{array}{l}\text { Bahasa Greek } \\
\text { (Yunani) }^{73}\end{array}$ \\
\hline \begin{tabular}{lr}
\multicolumn{2}{l}{ "Bertobatlah, } \\
sebab & Kerajaan \\
Sorga & sudah \\
dekat!" &
\end{tabular} & $\begin{array}{l}\text { Bertaubatlah, sebab } \\
\text { Kerajaan Syurga } \\
\text { sudah dekat }\end{array}$ & 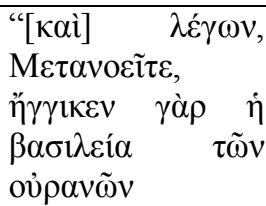 \\
\hline
\end{tabular}

Penggunaan kata taubat dalam Alkitab ${ }^{74}$ terjemahan Melayu pula ditulis dengan sebutan dan ejaan pelbagai. Di antaranya Alkitab Terjemahan Lama Kuno menulis kata taubat dengan kata Toucar, tawbat, taubat dan tobat ${ }^{75}$ yang

${ }^{70} \mu \varepsilon \tau \alpha v o \varepsilon ́(\omega, \mathrm{V} \backslash\{$ met-an-o-eh'-o $\}$ bermaksud 1) untuk mengubah minda seseorang, iaitu untuk bertaubat; dan 2) untuk mengubah minda seseorang menjadi lebih baik, sepenuh hati untuk memindah dengan rasa kebencian terhadap dosa masa lalu seseorang. Lihat: Greek Bible, http://www.greekbible.com/index.php, dicapai pada 17 Februari 2016.

71 Bagaimanapun metanoia dan metanoeo dalam Lukas 17:3 diterjemahkan kepada menyesal, sementara dalam Ibrani 12:17 sebagai memperbaiki kesalahan. Lihat Ensiklopedi Alkitab Masa Kini, 2:486.

${ }^{72}$ Perjanjian Baru dalam Yohannes 14: 1 \& 6. Lihat juga dalam Kisah Para Rasul 8:22; 26:18; dan 1 Petrus 2:25.

${ }^{73}$ Greek Bible.

${ }^{74}$ Alkitab, Lembaga Alkitab Indonesia, 1999.

75 Taubat dalam Alkitab Terjemahan Lama Kuno versi Brouwerius 1667 disebut 'toucar', versi Leydekker 1733 ditulis tawbat, dan dalam versi Keasberry 1853 dinukil 'taubat'. Manakala Alkitab Terjemahan Baru Indonesia cenderung menyebut kata 'tobat'. Sila rujuk

Sabda.org, 
bermaksud kembali atau menyesal. Manakala kata taubat dalam Bible berbahasa Inggeris bagi Perjanjian Lama dan Baru sering ditulis dengan kata 'repent' atau 'to turn'.

Istilah taubat atau repentance dalam terminologi Kristian telah wujud sejak zaman pra-Kristian lagi. Repentance telah diterjemahkan daripada kata metamonia dan metameleia yang diambil dalam buku Perjanjian Baru Greek. Smoley menyifatkan metamonia bermaksud perubahan dalam hala tuju kehidupan dengan cara menebus kesilapan dan memohon pertolongan Tuhan pada masa sekarang dan pada saat kematian. ${ }^{76}$

Manakala Jones menukilkan metamonia sebagai penukaran daripada kepercayaan lama kepada baharu, atau pemulihan dengan kepercayaan baharu melalui pengakuan dan berhenti melakukan dosa. ${ }^{77}$ Dapat difahami di sini bahawa pengertian metanoia pada zaman pra-Kristian adalah suatu perubahan fikiran mengenai seseorang atau sesuatu. Pada saat individu yang melakukan dosa tersedar lalu mengubah fikirannya, maka terjemahan bertaubat boleh diterima.

Para teologi Kristian berbeza pendapat ketika cuba mendefinisikan metamona sebagai repent atau taubat berikutan kepelbagaian penggunaan perkataan tersebut di dalam buku Perjanjian Baru yang datang dalam konteks yang pelbagai. Joshua dalam kajiannya telah merumuskan repent sebagai berpaling (turning away) dari semua perkara meliputi cara berfikir dan kehidupan kepada mempercayai Tuhan. ${ }^{78}$ Welsley pula mengertikan taubat sebagai perubahan hati dari semua dosa kepada kesucian,

http://alkitab.sabda.org:verse.php?book=Mat\&chapter=3\&verse=2, dicapai pada 4 Februari 2016.

${ }^{76}$ Richard Smoley, Inner Christianity (London: Shambhala, 2002), 5.

${ }^{77}$ Lindsay Jones, Encyclopedia of Religion, 7758

${ }^{78}$ Joshua D. Chatraw, "Jesus Theology of Repentance and Forgiveness as Both Individual and Coporate: A Response to N.T. Wright," (tesis kedoktoran, Faculty of Southeastern Baptist Theological Seminary, US: ProQuestLLC, 2013), 270. 
kerana itu dosa harus ditinggalkan dan perubahan harus terjadi. $^{79}$ Maksud taubat adakalanya diertikan 'kembali daripada dosa' seperti dosa tamak, menyembah berhala dan tidak beriman, di samping maksud kembali dalam bentuk mengubah pemikiran mengenai kerajaan dan Jesus penyelamat dan penebus dosa.

Carter ketika mengulas maksud repent mendapatinya datang dalam dua bentuk yang berlainan di antara repent sebagai sikap bertaubat melalui rasa penyesalan atau repent sebagai tindakan bertaubat melalui amalan. ${ }^{80}$ Menurut Ron Geaves pula, repentance ialah kutukan seseorang yang berdosa terhadap dosa yang dilakukannya, diikuti dengan mengembalikan kebergantungan dan kepatuhan kepada Tuhan. $^{81}$ Perjanjian Baru telah menggunakan pendekatan taubat melalui rasa penyesalan yang diikuti dengan perubahan tulus ikhlas dalam sikap seseorang.

Tuntasnya, taubat menurut Kristian adalah kesedaran dan rasa penyesalan yang telah mengubah fikiran individu dan membawa kepada mempercayai Tuhan. ${ }^{82}$

\section{Konsep Taubat menurut Kristian}

Perbincangan konsep taubat dalam ajaran Kristian sering kali melibatkan persoalan dosa warisan (original sin) dan pengorbanan Jesus Christ yang menjadi dasar terbentuknya doktrin utama dalam agama Kristian. ${ }^{83}$ Bermula dengan penciptaan manusia dalam 'gambar' dan

79 Paul Enns, The Moody Handbook of Theology: Buku Pegangan Teologi, terj. Rahmiati Tanudjaja, Sri Lestarini, Elisabeth Yuliasari (Malang: Literatur SAAT, 2010), 2:132.

80 John Carter, W. Jack, Repentance: Attitude or Action?, http://www.biblicaltheology.com/Research /CarterJ12.pdf, 5.

${ }^{81}$ Ron Geaves, Key Words in Christianity (London: The Continuum Int. Publishing Centre, 2006), 110.

${ }^{82}$ Di antaranya Amsal 1:23; Yeaya 31:6, 59:20; Yehexkiel 14:6; 18:31; 33:9-11; Yeol 2:12; Kisah 3:19; Ibrni 6:1

83 James Hasting, Encyclopaedia of Religion and Ethics (Scotland: T\&T Clark Edinburgh, 1994), 10:731. 
'rupa' Tuhan serta peristiwa kejatuhan Adam dan Eve seperti yang dirakam di dalam kitab Perjanjian Lama. ${ }^{84}$ Gereja Kristian mendakwa kejadian dosa pertama yang dilakukan oleh Adam dan Eve dengan memakan buah larangan merupakan punca asal dosa masuk ke dunia dan mewariskannya kepada zuriat Adam serta generasi seterusnya. Dosa tersebut dinamakan original sin dan disebut juga dosa warisan atau inherited sin.

Kepercayaan ini ditekalkan oleh pandangan St. Augustine yang turut menyatakan akibat daripada dosa Adam telah melahirkan kecenderungan berbuat dosa yang wujud dalam diri manusia. ${ }^{85}$ Aquinas juga setuju bahawa The Fall merupakan asas kepada kepercayaan dosa warisan yang berpunca daripada Adam dan Eve. Menurut Khadijah, pandangan kedua-dua tokoh Kristian ini memberi pengaruh yang besar terhadap perkembangan doktrin Kristian mengenai dosa warisan. ${ }^{86}$ Tidak keterlaluan jika dikatakan doktrin dosa warisan merupakan titik tolak kepada penetapan dan perkembangan doktrin lain dalam agama Kristian seperti baptis, pengakuan dosa (confession) dan penebusan dosa warisan.

Semua ini dihubungkaitkan dengan tragedi penyaliban Jesus yang dipercayai sebagai penyelamat (saviour) dan penebus dosa manusia yang telah diwarisi daripada Adam. ${ }^{87}$ Gereja Kristian mendakwa Tuhan

${ }^{84}$ Lihat ayat dalam Kejadian 1:26-27; 2:7, 20-25; 3:16-19, 22.

85 Augustine, The City of God against the Pagans, ed. R.W. Dyson, (United Kingdom: Cambridge University Press, 1998), xvi-xvii; Imam Muchlas Masyhud SM, Al-Qur'an Berbicara Tentang Kristen (t.t: Pustaka Da'I, 1999), 204; Lihat juga Perjanjian Lama, Mazmur 51: 5 dan Perjanjian Baru, Roma 5: 12-21.

86 Khadijah binti Mohd Khambali @ Hambali, "Interpretations of Eternal Tree (Shajarat al-Khuld) according to Christian Scholars and Mufassirun," (tesis kedoktoran, Jabatan Akidah dan Pemikiran Islam, Akademi Pengajian Islam, Universiti Malaya, 2004), 357.

${ }^{87}$ Lihat dalam Kitab Perjanjian Baru di antaranya Matius, Lukas, Mark, Yohannes dan 1 Korintus 1:17. 
dengan kasih sayangNya telah menyelamatkan manusia daripada dosa warisan yang menyebabkan terputus hubungan antara Tuhan dengan manusia. Justeru kasih sayang Tuhan diungkapkan dengan mengorbankan Jesus (son of man) di tiang salib dan mengalirkan darahnya bagi menebus dosa manusia. ${ }^{88}$

Pada masa yang sama, agama Kristian juga percaya bahawa manusia mempunyai dosa sendiri (actual sin) yang dilakukan mengikut kehendak manusia. Roman Katolik membahagikannya kepada Mortal Sin dan Venial Sin, sementara Protestan mengganggap dosa adalah tetap dosa tanpa membezakannya. Hal ini sejajar dengan pengertian dosa menurut Robert $^{89}$ secara umum adalah perlanggaran undang-undang Tuhan yang berlaku melalui perantaraan pemikiran, perkataan, perbuatan atau pengabaian. Justeru itu ajaran Kristian telah mengembangkan idea pertaubatan dengan maksud berbalik daripada cara hidup yang jahat kerana dosa, pergi kepada Jesus dan melaluinya kepada Tuhan. ${ }^{90}$ Percaya kepada ketuhanan dalam urusan dosa dan kebebasan berkehendak menjadikan taubat sebagai satu etika keagamaan. $^{91}$

Justeru itu, perbahasan taubat dalam Kristian penuh kontroversi berikutan kepelbagaian amalan konsep daripada pelbagai aliran yang wujud dalam agama ini. Pun begitu, pertaubatan dan pengampunan dalam teologi Kristian hanya terjadi jika ada perdamaian atau reconciliation $^{92}$ melalui pengorbanan Jesus di tiang salib

${ }^{88}$ Baharuddin Malek, Dosa Warisan, 201.

${ }^{89}$ Francesco Cardinal Robert, Dictionary of Moral Theology, 1134; William E. Addis, Catholic Dictionary, 76.

90 Perjanjian Baru ,Yohannes 14:1,6; Kisah Para Rasul 8:22; 26:18; dan 1Petrus 2:25

${ }^{91}$ James Hasting, Encyclopaedia of Religion and Ethics, 10:731

92 Ron, Key Words In Christianity, 110. Reconciliation juga disebut sebgai sakramen penukaran atau conversion, penyesalan atau penance, pegakuan dosa atau confessiom dan keampunan. Lihat 
bagi memulihkan semula hubungan antara manusia dengan Tuhan yang telah terputus sejak kejatuhan Adam dan Eve serta pewarisan dosa kepada semua manusia. ${ }^{93}$ Hal ini bermakna dosa warisan akan terhapus apabila penganut Kristian mengimani Jesus Christ sebagai penyelamat yang dikorbankan untuk menebus dosa mereka.

\section{a. Hukum Bertaubat}

Agama Kristian menganggap taubat satu perkara yang penting dan wajib dilakukan. Alkitab banyak menyebutkan kenyataan yang menunjukkan kepentingan bertaubat dan gesaan melakukan taubat. Suruhan bertaubat ini ditemui di dalam Perjanjian Lama dan Perjanjian Baru. Di antaranya (PL)Yesaya 31: 6, menukilkan "Bertobatlah, hai orang Israel, kepada Dia yang sudah kamu tinggalkan jauh-jauh!'94.

Malah penelitian terhadap kitab Perjanjian Baru sahaja, terdapat 13 daripada 58 pernyataan taubat direkodkan dalam bentuk perintah sama ada daripada Tuhan dan manusia. ${ }^{95}$ Ini jelas menunjukkan taubat sangat signifikan di dalam ajaran Kristian yang sering kali terkait dengan isu dosa dan pengampunan yang menjadi dasar pemberitaan Injil, doktrin dan sakramen gereja. ${ }^{96}$

Shaughnessy SW, Micheal, A Concise Catholic Catechism (New York: Burns \& Oates, 2002), 71.

${ }^{93}$ Ron, Key Words In Christianity, 108.

${ }^{94}$ Bible NKJV: Isaiah 31:6. The Holy Bible, New King James Version, (Nashville: Thomas Nelson, 1982), 403. Lihat juga NKJV: Mark $1: 15$.

${ }^{95}$ Perjanjian Baru, Matius 3:2, 4:17, Mark 1:15, 6:12, Lukas 13:3 \& 5, Kisah Rasul 2:38, 3:19, 8:22, 17:30, 26:20, Wahyu 2:5 \& 16, 3:3 \& 19.

96 Theodore M. Burton, Meaning of Repentance (t.tp: Brigham Young University Media Services, 1985), 5-9. 


\section{b. Ciri-Ciri Taubat}

Taubat adalah suatu perubahan dalam teologi Kristian, yang meliputi tiga aspek utama iaitu perubahan dari sudut fikiran, perasaan hati dan kehendak. Thiessen ${ }^{97}$ menjelaskan perubahan dalam bentuk fikiran ialah perubahan dari sudut pandangan terhadap dosa, Tuhan dan diri sendiri. Maksud dosa ialah kesalahan peribadi yang diakui individu kerana telah menyebabkan diri sendiri tercemar dan tidak berdaya memenuhi tuntutan Tuhan terhadap kebenaran.

Pada sisi lain, taubat juga meliputi perubahan fikiran terhadap Jesus dengan mengakuinya bukan seorang manusia biasa tetapi adalah Messiah atau 'juruselamat'. Sementara perubahan perasaan hati ialah merasa sedih dan menyesal atas dosa dan mengharapkan pengampunan. Ini kerana perasaan dukacita yang wujud menurut Paul adalah atas kehendak Tuhan yang menghasilkan pertaubatan dan membawa keselamatan. Manakala perubahan dari sudut kehendak ialah tindakan batiniyyah berupa kecenderungan hati dan tujuan untuk meninggalkan dosa. Apabila hati cenderung berubah akan mendorong seseorang berusaha untuk mendapatkan pengampunan dan penyucian.

Dari sudut praktik Kristian pula, taubat pada lazimnya memerlukan keadaan penuh penyesalan yang diikuti dengan perubahan tulus dalam sikap dan perilaku. Hal ini sesuai dengan pengertian taubat yang berupa penyesalan atas dosa yang dilakukan oleh seseorang individu. $^{98}$ Elemen tersebut perlu wujud pada setiap individu yang bertaubat berikutan kesepakatan The Council of Trent (1545-1563). ${ }^{99}$

97 Henry C. Thiessen, Lectures in Systematic Theoloy: Teologi Sistematika, ed. (Indonesia: Gandum Mas, 2010), 410-411.

${ }^{98}$ Ron, Key Words in Christianity, 110; James Gardner, Encyclopaedia of Faiths and Religions, 5:1636-1637

${ }^{99}$ Lindsay Jones, Encyclopedia of Religion, 7758. 
Dalam amalan gereja Roman Katolik, orang yang bertaubat perlu menjalani pengakuan dosa atau confession yang dilakukan di hadapan paderi yang bertanggungjawab merahsiakan perlakuan dosa tersebut. ${ }^{100}$ Di samping itu, pelaku dosa perlu mengakui bahawa dengan adanya anugerah daripada Tuhan, dia tidak akan melakukan dosa lagi. ${ }^{101}$ Lantaran itu penyataan sesal kepada Tuhan ditunjukkan dengan penggantian amalan kebajikan dalam bentuk 'doa', 'puasa' dan 'sedekah'. Semua syarat ini telah diadaptasi di dalam gereja Katolik dan taubat dalam bentuk penance atau penebusan dosa dijadikan sebagai salah satu sakramen gereja.

Bagi Martin Luther sebagai teraju Protestan telah menjadikan penyesalan satu-satunya syarat penerimaan taubat selagimana individu tersebut meyakini Jesus Christ adalah penyelamat manusia. ${ }^{102}$ Menurut Luther, perubahan fikiran melibatkan kesedaran bahawa Jesus adalah Tuhan dan juru selamat yang telah menebus dosa manusia dengan darahnya agar manusia boleh hidup dalam kerajaannya. ${ }^{103}$

Di samping itu, aliran Protestan menetapkan elemen emosi berupa hati yang menyesal tidak memerlukan tindak balas melalui perbuatan kerana keimanan terhadap Jesus penyelamat sudah cukup untuk menghapuskan dosa. Ini kerana Luther mengajarkan bahawa keimanan adalah anugerah Tuhan satu-satunya yang menjadi dasar keselamatan dan pengampunan dan perbuatan baik tidak mempunyai nilai untuk menyelamatkan manusia. Oleh itu, Luther menolak doktrin pengakuan dan pengampunan

100 James Gardner, Encyclopaedia of Faiths and Religions, 5:16361637.

101 Peter Chung, Tuhan, Terimalah Puji-Pujian Kami (Kuching: t.p., 1986), 37.

102 Martin Luther, Martin Luther's Basic Theological Writings, ed. Timothy E.Lull, William R. Russel (U.S.A: Fortress Press , 2012); Lindsay Jones, Encyclopedia of Religion, 7758.

${ }^{103}$ Enns, The Moody Handbook, 77. 
dosa yang menjadi praktik dalam sakramen suci Katolik di samping menolak penebusan dosa melalui amal kebajikan. ${ }^{104}$

Tuntasnya, taubat dalam Kristian adalah perubahan dalaman seseorang melalui tindakan dalam bentuk spiritual tanpa melibatkan tindakan fizikal bagi sesetengah aliran seperti Protestan. Manakala Roman Katolik mengakui taubat perlu kepada integrasi antara tindakan spiritual dan praktikal.

\section{c. Matlamat Taubat}

Jaminan keselamatan dalam kerajaan Tuhan dan syurga dijanjikan kepada mereka yang bertaubat sebelum mati. Keselamatan yang dimaksudkan ialah kebahagiaan dan kesejahteraan yang meliputi seluruh manusia sejagat dan segala aspek kehidupan. Keselamatan atau salvation dalam istilah Kristian ini merupakan matlamat utama masyarakat Kristian untuk terus kekal dalam ajaran Jesus Christ dan hidup dalam kemuliaan naungan Tuhan ${ }^{105}$.

Menurut Khadijah, istilah keselamatan telah digunakan oleh para teologi Kristin bagi mengungkapkan keadaan penganut Kristian yang bebas daripada tanggungan dosa dan hukuman dosa selepas kematian. Matlamat ini hanya boleh dicapai dengan sakramen tertentu. Di antaranya meyakini dalam upacara pembaptisan dan pengampunan bahawa Jesus Christ telah terpilih sebagai savior, messiah atau penyelamat dan penebus dosa warisan melalui penyaliban. ${ }^{106}$ Manakala keselamatan dan pelepasan daripada tanggungan dosa dan hukuman ini pula hanya diperolehi melalui penghapusan dosa yang menjadi tujuan pertaubatan Kristian. ${ }^{107}$

\footnotetext{
${ }^{104}$ Ibid., 79.

105 Khadijah Mohd. Hambali, "Konsep Salvation menurut Agama Kristian: Satu Huraian Awal," dalam Jurnal Usuluddin 10:10, (1999), 43-50.

${ }^{106}$ Ibid. .

107 Act 3:19: The Holy Bible, 629.
} 
Justeru, untuk mencapai keselamatan, pertaubatan menjadi salah satu perkara utama perlu ada bagi menonjolkan kunci keimanan kepada Tuhan semata-mata. Enns menukilkan pendapat John Wesley, teologi Protestan bahawa iman yang menyelamatkan meliputi empat hal iaitu: i. Kesadaran akan dosa; ii. Berpaling kepada Tuhan; iii. Pertaubatan dan pengakuan bahawa dosa telah memisahkan manusia dari anugerah Allah; dan iv. Iman kepada Jesus. ${ }^{108}$

Tiga hal pertama merupakan tindakan bertaubat sementara percaya Jesus Christ sebagai penyelamat yang diutus dan disalib untuk menebus semua dosa yang diwarisi manusia adalah tunjang 'keimanan' Kristian dan pintu keselamatan bagi penganut Katolik dan Protestan. ${ }^{109}$ Justeru Alkitab menegaskan bahawa individu yang berdosa telah disucikan dengan tanpa syarat selama mana dia beriman dan meyakini Jesus Christ sebagai satusatunya penyelamat dan penebus dosa yang sering dirujuk sebagai 'Tuhan Yang Pengampun'. ${ }^{110}$

Sungguhpun begitu, realitinya konsep keselamatan dan kerajaan Tuhan di dalam Kristian terlihat samar dan tidak pasti. Wright, sarjana teologi Kristian mempertikai ajaran Jesus tentang jaminan keselamatan kekal menerusi kehidupan selepas mati yang sekalipun telah banyak disebut di dalam Bible, ternyata Jesus tidak mengajarkan pengikutnya cara-cara untuk mendapatkan syurga selepas kematian. ${ }^{11}$ Menurut Wright lagi, kerajaan yang diperkenalkan oleh Jesus tidak menjanjikan apa-apa terhadap nasib manusia selepas mati. ${ }^{112}$

\footnotetext{
${ }^{108}$ Paul Enns, The Moody Handbook of Theology, 2:131

109 Ulfat Aziz-us-Samad, Islam and Christianity, 43; Lihat juga Perjanjian Baru dalam Kisah Para Rasul 20:21 dan 26:21.

110 Roma 3: 23-34. Alkitab, (Jakarta: Lembaga Alkitab Indonesia, 1999).

${ }^{111}$ Joshua D. Chatraw, Jesus Theology, 100.

${ }^{112}$ Ibid., 101.
} 


\section{d. Kuasa Pengampunan Taubat.}

Pengampunan merupakan tindakan undang-undang Tuhan dengan mengangkat dosa orang yang melakukan taubat. Pengkajian terhadap kuasa pengampunan dalam Kristian mendapati keterangan Alkitab yang menyatakan bahawa Tuhan akan mengampuni dosa orang yang bertaubat. Di antaranya Perjanjian Baru dalam Lukas 3:3 menyatakan "Bertobatlah dan berilah dirimu dibaptis dan Allah akan mengampuni dosamu." Begitu juga Kisah Para Rasul 8:22 "Jadi bertobatlah dari kejahatanmu ini dan berdoalah kepada Tuhan, supaya Ia mengampuni niat hatimu ini." 113

Kitab suci penganut Kristian dengan jelas menyatakan bahawa Tuhanlah yang berhak mengampunkan dosa-dosa orang yang bertaubat. Namun dalam ajaran Gereja pula telah memberikan kuasa pengampunan kepada manusia yang menjadi wakil Tuhan dalam urusan pengampunan dosa. Gereja Katolik secara umumnya telah melantik para paderi menjadi perantara (mediator) manusia yang berdosa dan Tuhan dengan memberikan kuasa pengampunan atau absolution. Kuasa pengampunan ini berlaku melalui pengakuan dan penebusan dosa di hadapan Pope atau paderi.

Menurut kepercayaan Kristian, Pope atau paderi adalah manusia yang suci daripada dosa (infallibility of papacy). Para paderi dipercayai mempunyai kuasa untuk mendengar dan menghapuskan dosa di dalam diri manusia. Mereka mendakwa memiliki kuasa mengampunkan dosa bersandarkan kepada para apostle telah mendapat tauliah daripada Jesus untuk memberi kemaafan dan pengampunan ke atas dosa-dosa manusia. ${ }^{114}$

${ }^{113}$ Alkitab, (cet.173, Jakarta: Lembaga Alkitab Indonesia, 1974). Lihat Kisah Para Rasul 2:38; Kisah Para Rasul 3:19; Bible NKJV Act 3:19, The Holy James Bible, New King James Version, (Nashville: Thomas Nelson, 1982), 9:29.

114 Baharuddin Malek, "Doktrin Dosa Warisan di dalam Agama Kristian dari Perspektif Roman Katolik: Suatu Analisis" (disertasi, Sarjana Usuluddin, Universiti Malaya, 1999), 
Dalam hal ini, gereja mengakui bahawa pemberian pengampunan itu bukan daripada paderi secara peribadi, tetapi adalah pemberian daripada Jesus yang menggunakan perantaraan paderi. ${ }^{115}$

Berbeza dengan Protestan, aliran ini tidak mengagungkan pastor atau pendeta mahupun menganggapnya suci. Malah tidak ada sistem kepausan dalam institusi gereja Protestan berbanding dengan gereja Katolik. Mereka juga tidak meletakkan kuasa pengampunan di tangan pastor sebaliknya mengakui setiap individu berhak memohon keampunan kepada Tuhan melalui Jesus. Walau bagaimanapun, mereka masih digalakkan menjalani pengakuan dosa secara berjemaah 'public order confession' kerana ianya memenuhi tujuan peribadatan. ${ }^{116}$

Pun begitu dalam menangani pengampunan dosa sesama manusia, Protestan memberikan kuasa sepenuhnya kepada manusia untuk memberi keampunan. Luther ${ }^{117}$ menyatakan bahawa Tuhan berjanji memberikan kempunan (forgiveness) dan menghapuskan dosa hanya

380. Schmucker menentang amalan private confession antara pastor atau pun parishioner sekalipun amalan ini telah diperakui di dalam Ausberg Confession. Beliau juga menentang dakwaan bahawa Gospel telah menyatakan bishops memiliki kuasa pengampunan dan ditauliahkan oleh Tuhan untuk mengajarkan Gospel berhubung dosa yang terhapus dan masih tersisa. Beliau menganggap doktrin absolutions dan sinforgiving suatu yang berbahaya terhadap doktrin justification by grace alone melalui keimanan (faith). Keampunan dan pembenaran hanya diperolehi melalui merits of Christ. Lihat Walter Sundberg, Worship as Repentance: Lutheran Lutheran Liturgical Traditions and Catholic Consensus (Cambridge U.K: William B. Edermans Publishing Company, 2012), 103-104.

${ }^{115}$ Lindsay Jones, Encyclopedia of Religion, 7758

${ }^{116}$ Sundberg, Walter, Worship as Repentance, 145.

117 John Nicholas Lenker, Luther's Catechetical Writings: God's Call to Repentance, Faith and Prayer (Minneapolis USA:The Luther Press, 1907), 1:151. 
jika penganut Kristian itu mengampunkan dosa individu lain terhadapnya ${ }^{118}$.

Menurut Smith, seseorang yang dizalimi harus mengampuni individu lain yang telah menzaliminya tanpa syarat. Tanpa pengampunan sebegini, individu yang dizalimi tidak akan dapat menjalani gaya hidup seorang Kristian, kerana dia akan sentiasa mengalami kepahitan hidup. Pengampunan ini merupakan langkah awal pembaharuan atau perubahan seseorang yang ingin bertaubat kepada Tuhan iaitu dengan memberi pengampunan kepada semua musuhnya sepanjang kehidupannya. ${ }^{119}$

Fahaman ini diambil daripada Kisah Para Rasul 7:60 dalam Alkitab Perjanjian Baru yang menyatakan:

"Maka berteriak-teriaklah mereka dan sambil menutup telinga serentak menyerbu dia. (7:58) Mereka menyeret dia ke luar kota, lalu melemparinya. Dan saksi-saksi meletakkan jubah mereka di depan kaki seorang muda yang bernama Saulus. (7:59) Sedang mereka melemparinya Stefanus berdoa, katanya: "Ya Tuhan Yesus, terimalah rohku." (7:60) Sambil berlutut ia berseru dengan suara nyaring: "Tuhan, janganlah tanggungkan dosa ini kepada mereka!" Dan dengan perkataan itu meninggallah ia."

Jelas, kuasa pengampunan dalam agama Kristian terletak di tangan manusia sama ada dimiliki oleh Jesus, para paderi dan orang awam daripada penganut Kristian. Ironinya Tuhan tidak mempunyai daya kuasa untuk memberi keampunan tanpa merujuk kepada manusia.

118 Dalam The Lord's Prayer penganut Kristian mengamalkan bacaan doa ini "And forgive us our debts, as we also forgive our debtors".

${ }^{119}$ Malcolm Smith, Kuasa Pengampunan, 12-16. 


\section{e. Proses dan Pelaksanaan Taubat}

Faktor masa dan peristiwa telah mengakibatkan proses bertaubat menjadi tidak konsisten dan sering mengalami perubahan impak dari tuntutan zaman dan kemunculan pelbagai aliran. ${ }^{120}$ Menurut Sundberg, beribadat atau worship dalam Kristian pada dasarnya adalah taubat. Sejajar dengan perintah Jesus dalam Mark 1:15 "bertaubat dan percayalah", Pope Benedict menyatakan bahawa ibadat mesti berasaskan taubat yang mana perkara tersebut telah diakui dalam ajaran Katolik dan Protestant. ${ }^{121}$

Wesley menyatakan bahawa taubat melibatkan tindakan yang harus dilakukan sebelum terjadi iman. ${ }^{122}$ Manakala tindakan bertaubat merupakan amalan yang diwajibkan melalui sakramen atau ritual-ritual tertentu. Gereja Kristian seperti Katolik dan Ortodoks menetapkan tujuh sakramen yang perlu diamalkan iaitu baptis, confirmation, perjamuan suci (Eucharist), pengakuan dosa (penance), Holy Order, marriage dan Extreme Unction.

Manakala aliran Protestan lazimnya hanya menekankan dua sakramen yang mereka takrifkan sebagai peraturan dan tanda kekristianan. Sakramen ini merupakan upacara peribadatan dalam gereja dan merupakan amalan yang berhubung kait dengan taubat dalam usaha menghapuskan dosa dan memohon keampunan.

Sebagai contoh, menurut Katolik, praktik baptis perlu dilakukan kepada bayi untuk menghapuskan kekotoran dosa warisan yang menghalang jiwa bayi tersebut memasuki kerajaan Syurga. ${ }^{123}$ Sebaliknya Prostestan cenderung menjalankan baptis ke atas remaja atau dewasa berbanding anak-anak yang belum memahami maksud

\footnotetext{
120 William H. Brackney, Studying Christianity the Critical Issues (New York: Continuum, 2010), 79.

${ }^{121}$ Walter Sundberg, Worship As Repentance, 168-169.

${ }^{122}$ Paul Enns, The Moody, 2:132.

${ }^{123}$ Ibid..
} 
iman serta belum mengerti tanggungjawab sebagai Kristian. Hal ini sejajar dengan amalan baptis yang pada awalnya dijalankan kepada orang dewasa sepertimana yang berlaku lebih dahulu kepada John the Baptist dan Jesus. ${ }^{124}$ Untuk itu baptis menurut Protestan dilakukan apabila individu telah mencapai tahap umur yang membolehkannya memahami keperluan baptis dalam Kristian. Di dalam Matius 28:19 dinyatakan, "Pergilah dan buatlah orang dari segala bangsa menjadi murid, baptislah mereka."

Dalam hal ini, Smoley, William dan Lyden setuju menyatakan baptis secara umumnya melibatkan pertaubatan untuk mendapatkan keampunan dosa ${ }^{125}$ seperti direkodkan dalam Gospel Luke 3:3 ${ }^{126}$ di samping penerimaan anugerah Tuhan serta keputusan untuk mengikut Tuhan. ${ }^{127}$ Apabila seseorang itu dibaptis, akan berlaku penyerapan rahmat kepada orang yang percaya serta menjadi titik mula penggabungan ke dalam gereja. ${ }^{128}$ Justeru individu yang ingin menganut agama Kristian perlu menjalani ritual baptis sebagai bukti tanda pertaubatannya kerana sebelum ini berpaling daripada Tuhan Kristian. Namun kini individu itu telah berbalik kepada Tuhan dan masuk ke dalam kerajaan Tuhan serta menjadi jemaat Kristian melalui pengakuan beriman kepada Jesus.

Kisah Para Rasul 2:38 menyebut "Bertobatlah dan hendaklah kamu masing-masing memberi dirimu dibaptis dalam nama Yesus Kristus untuk pengampunan dosamu, maka kamu akan menerima karunia Roh Kudus". ${ }^{29}$ Proses taubat melalui pembaptisan dilakukan dengan bermacam

\footnotetext{
${ }^{124}$ Richard Smoley, Inner Christianity, 211.

${ }^{125}$ Ibid., 21,

${ }^{126}$ Perjanjian Baru, Lukas 3:3.

127 John Lyden, "From Sacrifice to Sacrament", 51.

128 Brackney, William H., Studying Christianity The Critical Issues (New York: Continuum, 2010), 80.

${ }^{129}$ Alkitab, 155.
} 
kaedah, sama ada dengan renjisan air, celupan ke dalam air sebanyak tiga kali atau melakukan selaman seluruh badan untuk beberapa saat sebagai simbol pembersihan daripada dosa. ${ }^{130}$

Kaedah kedua dalam proses bertaubat dijalankan melalui praktikal pengakuan dosa. Dalam ajaran Kristian Katolik, proses ini dinamakan penance dan merupakan salah satu sakramen penebusan dosa. Amalan penance merangkumi tiga perkara iaitu sesi pengakuan dosa (confession), sesi penyesalan (contrition) dan sesi pemberian pengampunan (absolution) yang diumumkan oleh Paderi kepada individu yang melakukan confession. ${ }^{131}$ Pemusatan terhadap gereja sebagai satu-satunya institusi terpenting dalam hal ehwal keagamaan, serta pengagungan dan penyerahan total kepada paderi sebagai seorang yang suci, menuntut penganut Katolik untuk hanya menjalani ibadat dan proses pertaubatan di gereja.

Justeru setiap penganut Katolik yang tersedar dari perlakuan dosa dan ingin bertaubat harus mendatangi gereja bagi menjalani proses pertaubatan melalui pengakuan dan penebusan dosa di hadapan seorang paderi. Dosa yang perlu diperakui ialah dosa yang dikerjakan melalui perbuatan zahir; pengakuannya dilakukan secara lisan dengan menyebut bentuk dan jenis dosa yang diperbuat. Pengakuan menjadi batal dengan sendirinya apabila tidak jujur dalam ungkapan pengakuan. Setelah pengakuan dosa selesai, paderi akan memberikan pengampunan absolution dengan mengumumkan pembebasan individu yang bertaubat daripada dosa dan hukuman, ${ }^{132}$.

${ }^{130}$ William H. Brackney, Studying Christianity the Critical Issues, 80; Abdul Hamid Qadri, Dimensi Keimanan Kristen, terj. Masyhur Abadi \& Lis Amalia R (T.T: Pustaka Da'i, 1999), 117.

${ }^{131}$ William H. Brackney, Studying Christianity The Critical Issues, 81.

${ }^{132}$ Geoffrey Parrinder, A Concise Encyclopedia of Christianity (New York: Oneworld Publications, 2001), 14; Walter Sundberg, Worship as Repentance, 115-116. 
Pada abad pertengahan, proses ini diikuti dengan tindakan penitential sebagai tanda penyesalan meliputi puasa, pengekangan nafsu (continence), melawat tempat suci (pilgrimage) atau pemenjaraan (imprisonment). ${ }^{133}$ Walaubagaimanapun, kaedah ini berubah setelah berlangsung Vatican II pada tahun 1963 iaitu proses ini dilakukan melalui perdamaian (reconciliation), doa, pembacaan kitab dan pengakuan secara persendirian (private confession) di dalam ruang bilik tertutup antara confessor dan paderi. ${ }^{134}$ Menurut Parrinder, pada masa era kekuasaan gereja, dipercayai bahawa kuasa untuk menghapus kesalahan-kesalahan individu yang berdosa telah diberikan kepada para rasul atau paderi, ${ }^{135}$ begitu juga janji untuk mendapat kunci kerajaan telah lebih dahulu disediakan untuk mereka. ${ }^{136}$

Dalam pada itu, gereja Katolik menekankan bahawa pengakuan dosa harus dilakukan setidak-tidaknya sekali dalam setahun. ${ }^{137}$ Praktikal ini turut diperakui oleh Kristian Ortodoks dengan membina teori bahawa cuping telinga paderi yang mendengar sesi pengakuan dosa ibarat telinga Tuhan. ${ }^{138}$

Kristian Protestan pula lebih bersifat terbuka dalam menangani proses pertaubatan. Sekalipun gereja masih dianggap institusi penting melibatkan kelangsungan hubungan sesama komuniti Kristian, aktiviti pengajaran Alkitab dan ritual keagamaan. Kristian Protestan membenarkan acara pembaptisan dan pertaubatan berlangsung di luar gereja. Malah terdapat sebahagian gereja Protestan seperti Gereja Inggeris tidak mempraktikkan penance sementara gereja lain hanya

\footnotetext{
${ }^{133}$ William H. Brackney, Studying Christianity The Critical Issues, 81. ${ }^{134}$ Ibid..

${ }^{135}$ Matius 16:19 dan John 20:23.

${ }^{136}$ Geoffrey Parrinder, A Concise Encyclopedia of Christianity, 14.

137 Abujamin Roham, Ensiklopedia Lintas Agama (Jakarta: Emerald, 2009), 575.

${ }^{138}$ Lindsay Jones, Encyclopedia of Religion, 7758.
} 
menggalakkan pertaubatan dan pengakuan dosa dilakukan ketika upacara kebaktian (Holy Communion) dijalankan. ${ }^{139}$

Para pelaku dosa yang tersedar daripada kesilapannya berhak memohon keampunan kepada Tuhan secara langsung tanpa bergantung kepada ketua agama atau pentadbir gereja. Protestan menolak kaedah pertaubatan Katolik kerana tidak terdapat di dalam Alkitab. Untuk itu, sesi pertaubatan dalam kalangan Protestan boleh berlaku dengan kerap di mana-mana sahaja dan pada bila-bila masa. Keyakinan terhadap kasih sayang Tuhan dijadikan jaminan bahawa setiap pelaku dosa yang bertaubat akan menerima keampunan Tuhan dengan mudah tanpa perlu berkerja keras atau menerima hukuman pembalasan.

Jelas, wujudnya kepelbagaian proses dan perlaksanaan taubat dalam Kristian sesuai dengan kepelbagaian aliran di samping tuntutan peredaran masa sehingga mempengaruhi kepercayaan dan proses bertaubat sekalipun taubat diperakui asas penting di dalam agama Kristian.

Pentaubatan di dalam agama Kristian juga dilakukan ketika mengadakan Perjamuan Suci (Eucharist) yang sangat mengesankan hati penganut Kristian. Sakramen ini juga dinamakan "the mass", "Holy Communion", "the Lord's Supper" dan bagi Gereja Timur Ortodoks, "the Divine Liturgy" mengandungi upacara makan roti dan wain yang dijadikan simbol jasad dan darah Jesus Christ. Penganut Katolik dan Protestan berbeza pendapat mengenai keadaan penyertaan Jesus pada upacara tersebut antara kehadiran secara fizik atau cuma roh sahaja turut bersama. ${ }^{140}$ Penganut Kristian percaya bahawa dengan makan roti dan minum wain, dosa individu yang berdosa akan terhapus atau diampunkan. ${ }^{141}$

\footnotetext{
${ }^{139}$ William H. Brackney, Studying Christianity The Critical Issues, 81.

${ }^{140}$ Paul Enns, The Moody Handbook of Theology, 2:82.

${ }^{141}$ Perjanjian Baru, Matius. 26:28.
} 
Berdasarkan perbincangan di atas, disimpulkan bahawa Gereja Katolik dan Protestan menyifatkan taubat sebagai kaedah mengembalikan hubungan manusia dengan tuhan yang terputus akibat perlakuan dosa. Justeru setiap pengamal Kristian wajib bertaubat ${ }^{142}$ dengan menjalani ritual pembaptisan ${ }^{143}$ sekurang-kurangnya sekali seumur hidup ${ }^{144}$ sebagai tanda penghapusan dosa serta simbol keahlian gereja. Amalan dalam agama Kristian ini mirip dengan praktik agama Pagan yang dominan mempengaruhi masyarakat Kristian suatu masa dulu melalui pengajaran kepada para pendeta tentang keupayaan mengampunkan dosa manusia.

\section{Analisis Persamaan Taubat dalam Islam dan Kristian}

Secara umum, terdapat persamaan dalam pendefinisian taubat sebagai kembali, berpaling dan penyesalan menurut sudut pandangan Islam dan Kristian. Begitu juga konsep taubat meliputi hukum bertaubat menunjukkan kewajipan mengamalkan taubat pada kedua-dua agama.

Peranan taubat untuk memulihkan hubungan antara manusia dengan Tuhan yang telah rosak kerana perlakuan dosa turut diakui oleh Islam dan Kristian. Dari segi matlamat juga didapati adanya persamaan antara Islam dan Kristian di mana keampunan menjadi tujuan untuk mendapatkan keselamatan dan syurga sekalipun terdapat perbezaan dari sudut pemahaman maksud keselamatan yang akan dibahas di dalam bahagian selepas ini.

\section{Analisis Perbezaan Taubat dalam Islam dan Kristian}

Analisis terhadap konsep taubat dalam Islam dan Kristian mendapati beberapa perkara yang menunjukkan wujudnya perbezaan konsep antara dua agama yang akan dirincikan seperti berikut:

\footnotetext{
${ }^{142}$ Matius 4:17, \& Mark 1: 15.

${ }^{143}$ Alkitab Perjanjian Baru, Matius 3:5-12

${ }^{144}$ Aliran di dalam Kristian masing-masing berbeza pendapat dari sudut bila waktu dan di mana tempat baptis perlu dilaksanankan.
} 


\section{a. Penggunaan Terminologi Taubat}

Melihat kepada terminologi taubat dalam Kristian difahami bahawa isu taubat yang menuntut perubahan hanya menyentuh aspek moral dan urusan keagamaan yang menjadi simbol kepada keimanan terhadap Jesus bagi mendapat keselamatan dan keampunan Tuhan. Justeru asas keyakinan agama Kristian dizahirkan dalam bentuk ritual keagamaan sama ada melalui pembaptisan dan pengakuan dosa. Hal ini jauh berbeza dengan terminologi taubat di dalam Islam yang lebih luas mencakup pelbagai disiplin ilmu.

Sebagai contoh, perbincangan taubat yang menuntut penyesalan dan berhenti melakukan dosa dalam ilmu Fiqh sering dilihat dari sudut undang-undang dan hukuman yang mengakibatkan tindakan atau pelepasan dunia dan akhirat. Manakala perbahasan taubat dalam ilmu Kalam cenderung menekankan soal akidah dan keimanan, kehendak dan ketentuan dalam diri manusia dan hubungannya dengan Allah.

Sementara bicara taubat dalam ilmu Tasawwuf lebih halus dan mendalam kerana sinonim dengan kaedah penyucian jiwa dan perjalanan hati mendekati Allah dan mengenaliNya. Justeru taubat menurut perspektif Islam adalah menyeluruh dalam semua aspek kehidupan manusia.

\section{b. Konsep Taubat}

Penelitian terhadap konsep taubat di dalam Islam dan Kristian pula mendapati terdapat titik perbezaan dalam konsep taubat secara menyeluruh sama ada dari segi ciriciri, matlamat, autoriti memberi keampunan dan proses perlaksanaan taubat. Sememangnya diakui bahawa Islam dan Kristian sama-sama menyuguhkan taubat sebagai sarana untuk memulihkan hubungan yang tercalar antara manusia dengan Tuhan akibat dosa. Namun sudut pandang yang berbeza terhadap konsep dosa dan pelakunya telah membawa kepada penilaian yang berbeza pula terhadap 
implikasi dan tuntutan bertaubat daripada dosa. Pebincangan analisis bagi perkara ini akan dijelaskan dengan menilai sebab taubat diwajibkan dan bagaimana melaksanakan taubat yang dituntut agama:

i. Dari aspek hukum taubat, seruan bertaubat dalam Kristian ditujukan kepada semua manusia tanpa mengira agama agar mereka menjadi orang yang percaya kepada Jesus, mendapat keselamatan dan masuk ke dalam kerajaan Tuhan. Ajakan bertaubat ini menuntut manusia kembali dan berpaling daripada dosa kepada Tuhan melalui keimanan kepada Jesus. Namun gereja Kristian meletakkan syarat untuk selamat dengan mewajibkan taubat daripada dosa yang dilakukan oleh setiap individu di samping keperluan bertaubat daripada dosa yang tidak pernah dilakukannya yang merujuk kepada original sin.

Justeru, setiap individu hanya akan bebas daripada inherited sin dan actual sin dengan bertaubat melalui kaedah dan proses yang ditetapkan oleh gereja. Sebaliknya hukum taubat dalam Islam menjadi wajib disebabkan dosa yang dilakukan sendiri oleh setiap individu tanpa membebankan dosa orang lain. Hukum ini berlaku kepada semua Muslim dan juga non-Muslim (yang berkecenderungan menganuti Islam).

ii. Taubat dalam ajaran Protestan menuntut perubahan dalaman seseorang melalui tindakan spiritual dengan mengandaikan keimanan kepada Jesus Christ sematamata mampu untuk meraih keampunan Tuhan dan menjamin keselamatan individu yang percaya dalam Jesus Christ.

Begitu pula keimanan adalah anugerah Tuhan satu-satunya yang menjadi dasar keselamatan dan pengampunan di mana perbuatan baik tidak mempunyai nilai untuk menyelamatkan manusia. 
Kristian Katolik melazimkan pengakuan dosa dan penebusan dosa di hadapan paderi sebagai amalan pertaubatan. Justeru ciri-ciri taubat menurut aliran Katolik merupakan integrasi antara tindakan spiritual dan praktikal materi.

Hal ini berbeza dengan ciri-ciri taubat di dalam Islam yang menekankan keikhlasan dalam bertaubat semata-mata kerana Allah serta azam bersungguhsungguh tidak mengulangi semula dosa-dosa tersebut pada masa akan datang. Untuk itu, individu bertaubat perlu mengetahui bahawa perkara yang dilakukan itu adalah dosa kerana dengan ada elemen intelek tersebut akan menimbulkan perasaan kesal dan azam berhenti daripada dosa. Namun tidak cukup setakat intelek dan emosi, bahkan harus dibuktikan pula dengan tindakan berupa amalan kebaikan sebagai ganti daripada kebiasaan melakukan dosa.

iii. Tidak dinafikan matlamat taubat di dalam Islam dan Kristian adalah sama iaitu penghapusan dosa dan masuk syurga. Bagaimanapun perbezaan didapati dari sudut cara mencapai matlamat tersebut. Kristian mensyaratkan keimanan kepada Jesus penyelamat kerana menganggap iman itu adalah taubat dan taubat itu adalah iman. Adapun Islam menuntut amalan ibadat di samping ketaatan dan taubat yang telus kepada Allah sebelum mendapat balasan syurga.

iv. Dari sudut kuasa pengampunan terhadap amalan bertaubat, Islam secara adil telah meletakkan hak ketuhanan dalam memberi pengampunan bagi yang bertaubat. Penekanan bahawa dengan memberi penekanan hanya Allah yang berhak menghapuskan dosa individu yang bertaubat dan memberikan keampunan kepada mereka. Di sebalik penyataan ini terkandung penafian kuasa manusia menghapuskan 
dosa mahupun memberi keampunan seperti mana dakwaan dalam doktrin Kristian.

Begitu pula jaminan untuk masuk ke dalam syurga yang merupakan matlamat daripada suruhan bertaubat adalah hak mutlak Allah S.W.T dan manusia tidak mempunyai pengetahuan sedikit pun mengenainya. Dalam pada itu, Islam memperakui peranan manusia dan hak-haknya dengan memperuntukkan keredaan manusia yang dizalimi untuk memberi ampun atau menuntut bayaran ganti kerosakannya jika kesalahan menyangkut hak-hak manusia.

Berbanding dengan kuasa pengampunan taubat dalam Kristian, terdapat percanggahan antara teori dan praktikal. Alkitab yang menjadi sumber rujukan Kristian dengan jelas menyatakan bahawa keampunan itu adalah milik Tuhan. Bagaimanapun dalam amalan praktikal, penganut Kristian terpaksa akur dengan ajaran gereja yang memberikan kuasa pengampunan kepada manusia dan menafikan hak Tuhan. Gereja Katolik telah menjadikan paderi sebagai pengantara mediator antara manusia dengan Tuhan lalu memberi kuasa sepenuhnya kepada paderi untuk memberi keampunan dosa yang diperakui dihadapan mereka.

Manakala pengamal aliran Prostestan tidak perlu menjalani proses pengakuan dosa di hadapan paderi kerana meyakini kuasa pengampunan bukan ditangan mereka. Pun begitu, permohonan ampun kepada Tuhan masih perlu melalui Jesus dan dakwaan Kristian terhadap peranan Jesus sebagai penyelamat (saviour) manusia ialah untuk menghapuskan dosa dan menjamin keselamatan setiap individu yang percaya. Justeru sekali lagi kuasa Tuhan sebagai pencipta dinafikan di dalam agama Kristian. 
Dalam menangani dosa yang bersangkutan dengan hak manusia, Protestan pada zahirnya memberi hak kepada individu yang dizalimi untuk mengampuni pelaku kesalahan yang memohon keampunannya. Bagaimanapun individu yang dizalimi haknya atau pihak mangsa ini telah dipaksa dengan tidak mempunyai pilihan agar mengampunkan kesalahan pemangsa. Dalam doktrin Kristian, penganut agama ini perlu memaafkan kesalahan individu lain terhadapnya agar dia sentiasa mendapat keampunan Tuhan bagi setiap dosa.

v. Pada menilai perbezaan proses dan pelaksanaan taubat menurut Islam dan Kristian, perkataan ampun menjadi sinonim dalam kedua-dua agama yang mana pengampunan merupakan salah satu matlamat bertaubat dalam Islam dan Kristian. Justeru Islam memandang taubat adalah proses untuk mendapatkan keampunan, sementara pengampunan adalah natijah yang dicapai setelah proses taubat dilaksanakan.

Manakala proses dan pelaksanaan taubat dalam Kristian memperlihatkan suatu perjanjian yang pasti antara manusia dan Tuhan untuk mendapatkan keselamatan. Manusia akan selamat apabila bertaubat. Taubat adalah keimanan kepada Jesus sebagai penyelamat manusia dan penebus dosa. Namun untuk bertaubat atau dengan kata lain ber'iman' dengan Jesus, maka penganut Kristian harus pula melaksanakan proses taubat yang terdiri daripada ritual dan sakramen-sakramen suci yang telah dietapkan oleh Gereja.

Islam mensyaratkan taubat untuk berhenti melakukan dosa bil quwwah dan bil fi'l, maka taubat di dalam ajaran Kristian hanya sampai ke tahap bil fi'l. 


\section{Ulasan}

Berasaskan perbincangan tersebut, agak jelas bahawa persamaan yang wujud antara Islam dan Kristian dalam isu taubat hanya menyentuh aspek istilah yang sama-sama digunakan oleh kedua-dua agama. Walau bagaimanapun pemahaman terhadap isi kandungan konsep taubat menunjukkan perbezaan yang ketara. Ini kerana kajian mendapati taubat yang diterapkan dalam agama Islam memberi hak 'kembali' kepada Allah S.W.T selaku pencipta, pemberi taubat, pemberi ampun dan pemberi ganjaran syurga. Justeru semua amalan pertaubatan mesti menuju arah kepada Allah semata-mata sehingga berlangsungnya hubungan dua hala antara Allah kepada manusia dan sebaliknya.

Adapun taubat dalam Kristian cenderung mementingkan kerohanian tanpa batasan sehingga menggugat hak diri individu. Di antaranya, ajaran gereja Katolik yang menjadikan amalan taubat terlaksana antara pendosa dan Tuhan dengan perantaraan paderi menerusi pengakuan dosa. Lebih daripada itu, Martin Luther pelopor aliran Protestan mendakwa keimanan kepada Jesus yang disalib sebagai penyelamat manusia dan penebus dosa sudah cukup untuk melayakkan seseorang Kristian mendapatkan keampunan dan diterima taubat.

Justeru keampunan dosa diperolehi dengan mudah tanpa perlu mengganti semula kerosakan dan kezaliman yang telah dilakukan, sekalipun melibatkan pihak ketiga daripada kalangan manusia. Pada masa yang sama, taubat dalam agama Kristian tidak mengembalikan hak Tuhan sebagai pencipta, pemberi taubat, pemberi ampun dan pemberi keselamatan sekalipun kitab suci mereka mengarahkan sedemikian.

Tegasnya, taubat bukan hanya sekadar isu moral dan urusan agama, bahkan lebih daripada itu taubat mencakupi semua bentuk kehidupan manusia. Taubat dalam Islam adalah intipati dan agen kepada setiap perubahan diri 
individu Muslim secara fizikal dan spiritual. Justeru, taubat menjadi wajib dan perlu disegerakan agar setiap insan sentiasa kembali mentaati Allah. Konsekuensi daripadanya adalah penerimaan dan pengiktirafan Allah ke atas segala ibadat yang dilakukan hasil hubungan langsung manusia dengan Allah Maha Kuasa.

Elemen ini tidak terdapat di dalam Kristian kerana taubat yang dilakukan sebagai proses taubat dan pengampunan dosa melalui pengakuan dalam Kristian Katolik contohnya hanya terjadi di antara sesama manusia iaitu paderi atau ketua gereja dan pelaku dosa serta masyarakat sekeliling tanpa wujud hubungan hakiki antara manusia dengan Tuhan. Manakala proses taubat dalam Protestan yang mengandaikan iman semata-mata telah mengabaikan unsur fizikal dan jasmani serta menafikan peranan manusia dalam kehidupan bermasyarakat.

\section{Rujukan}

Ābadī, Fayrūz. Al-Qāmūs al-Muhịṭ. Cet. 6. Beirut: Mu'assasah al-Risālah, 1998.

Ābadī, Fayrūz. Al-Qāmūs al-Muhìt. Damsyik: Maktabah al-Nūrī, t.t.

Abujamin Roham. Ensiklopedia Lintas Agama. Jakarta: Emerald, 2009.

Alkitab@LAI 1974. Jakarta: Lembaga Alkitab Indonesia, 1999.

Anisah. Konsep Keselamatan dalam Teologi Kristen Modern. Tesis Sarjana-1, Institut Agama Islam Negeri Walisongo, 2008.

Burhan Djamaluddin. Konsepsi Taubat. Surabaya: Dunia Ilmu, 1996.

Burton, Theodore M. Meaning of Repentance. T.t: Brigham Young University Media Services, 1985.

Calvin, John. The Institutes of Christian Religion. ed. Tony Lane \& Hilary Osborne. Grand Rapids, MI: Baker Bookhouse, 1987. 
Carter, John W. Jack. Repentance: Attitude or Action? http://www.biblicaltheology.com/Research /CarterJ12.pdf'.

Chatraw, Joshua D. Jesus Theology of Repentance and Forgiveness as Both Individual and Coporate: A Response to N.T. Wright. Tesis kedoktoran, Faculty of Southeastern Baptist Theological Seminary, US, 2013.

Eliade, Mircea., ed. The Encyclopedia of Religion. USA: Macmillan Library Reference, 1995.

Ellwood, Robert S. \& Alles, Gregory D. The Encyclopedia of World Religions. USA: Facts On File, Inc, 1998.

Geaves, Ron. Key Words in Christianity. London: The Continuum Int. Publishing Centre, 2006.

Al-Ghazālì, Abū Hāmid Muhammad bin Muhammad. Ihyā' 'Ulūm al-Dīn. ed. Al-Shihāt al-Ṭaḥān, 'Abdullah al-Minsharí. Al-Manșūrah: Maktabah al-Imān, 1996.

Al-Ghazālì, Abū Hāmid Muhammad bin Muhammad. Minhāj al-'Ābidīn, terj. Zakaria Adham. Selangor: Victory Agencie, 2011.

Hajah Noresah Baharom ed. Kamus Dewan. Kuala Lumpur: Dewan Bahasa dan Pustaka, 2010.

Hasting, James. Encyclopaedia of Religion and Ethics. Scotland: T\&T Clark Edinburgh, 1994.

Hawkins, Joyce M., ed. Kamus Dwibahasa Oxford Fajar. Shah Alam: Oxford Fajar Sdn. Bhd. 2008.

Ibn Ahmad al-Azhari. Mu'jam Tahzib al-Lughah. Beirut: Dar al-Ma 'rifah, t.t.

Ibn Kathir, Abū al-Fidā' Ismā'īl. Tafsīr al-Qur'ān al'Azīim, tahqiq, Muștafā al-Sayyid Muhammad. Giza: Mu'assasah Qurțubah, t.t.

Ibn Majāh, Muhammad bin Yazīd. Sunan Ibn Majāh. Riyadh: Maktabah al-Ma ārif, t.t.

Ibn Manzūur. Lisān al-'Arab. cet.3. Beirut: Dār Ihyā' alTurāth al-'Arabi, 1999.

Ibn Qayyim al-Jawziyyah, Muḥammad bin Abī Bakr bin Ayyūb. Madārij al-Sālikīn: Bayn Manāzil Iyyāk Na 'bud 
wa Iyyāk Nasta'īn, tahqiq. Rị̣wān Jāmi‘ Rị̣wān. Kaherah: Mu'assasah al-Mukhtār, 2001.

Ibn Zakariyā, Aḥmad bin Fāris. Mu jam Maqāyyis alLughah. Beirut: Dār Ihyyā' al-Turāth al-'Arab̄̄̄, 2001.

Jones. Encyclopedia of Religion. ed. 2. USA: Macmillan Reference, 2005.

Luther, Martin. Martin Luther: Selections from His Writing. Random House LLC, 2011.

Luther, Martin. Martin Luther's Basic Theological Writings. ed. Timothy E. Lull, William R. Russel, cet. 3. U.S.A: Fortress Press, 2012.

Al-Muhasibí, āl-Hārith bin 'Asad. Al-Tawbah, ed. 'Abd al-Qādir Ahmad 'Atțā'. Kaherah: Dār al-Faḍilah, t.t.

Al-Nawāwī. Riyāẹ al-Șālihīn. Beirut: Al-Maktabah alIslāmiyyat, 1979.

Qadri, Abdul Hamid. Dimensi Keimanan Kristen, terj. Masyhur Abadi \& Lis Amalia R. t.tp: Pustaka Da'i, 1999.

Al-Qaraḍāwī, Yūsuf. Al-Ṣaḥwah al-Islāmiyyah Bayn alJuhūd wa al-Tațarruf, cet.7. Beirut: Mu'assasah, 2000.

Al-Qaraḍāwì, Yūsuf. Al-Tawbah ilā Allāh. Kaherah: Maktabah Wahbah, 1998.

Al-Qaraḍāwī, Yūsuf. Kalimāt fī al-Wasațiyyah alIslāmiyyah wa Ma 'ālimuhā. Kuwait: Huliy, 2007.

Al-Qinūjī al-Bukhāri, Șiddiq bin Hasan bin 'Alì alHusayn. Fath al-Bayān fï Maqāṣid al-Qur'ān. Beirut: al-Maktabah al-'Așriyyah, 1992.

Al-Qurțūbī, 'Abdullāh Muḥammad bin Aḥmad. al-Jāmi ' $l i$ Ahkam al-Qur'ān, ed. Sālim Muștafā al-Badrī. Beirut: Dār al-Kutub al-'Ilmiyyah, 2000

Al-Qushayrī, Abd al-Qāsim 'Abd al-Karīm. al-Risālat alQushayriyyah fï 'Ilm al-Tașawwuf. Kaherah: Dār alKutub al-Hadìth, t.t.

Al-Rāzì, al-Fakhr. Al-Tafsìr al-Kabīr, cet. 3. Beirut: Dār Ihyā' al-Turāth al-‘Arabì, 1999. 
Sri Rahayu \& Khadijah, "Konsep Taubat menurut Islam dan Kristian," Afkār Vol. 18 Issue 1 (2016): 43-90

Sami bin Abdullah al-Maghlouth. Atlas Agama-Agama. Jakarta: Almahira, 2012.

Sayyid Qutb. Tafsìr fī Zilāl al-Qur'ān, terj. Yusoff Zaky Yacob. Kelantan: Pustaka Aman Press Sdn. Bhd, 2000.

Smoley, Richard. Inner Christianity. London: Shambhala, 2002.

Tafsir Pimpinan Ar-Rahman kepada Pengertian AlQur'ān. Malaysia: Darulfikri, t.t.

Zainal Kling. "Konsep Wasatiyyah: Perspektif Sosial Sains." Kertas kerja Konvensyen Wasatiyyah, Nadi Dialog Masa \& Jabatan Kemajuan Islam Malaysia, t.t. 